\title{
Changes in Consumer Perspective towards Discount at Brick-and-Mortar Stores owing to Emergence of Online Store Format in India
}

\author{
H.R. Ganesha ${ }^{1}$, P.S. Aithal ${ }^{2}$, \& P. Kirubadevi ${ }^{3}$ \\ ${ }^{1}$ Chief Executive Officer - Consulting Division, Gramss Retail Trading Private Limited, \\ Bengaluru - 560078, India and Post-Doctoral Research Fellow, College of Management\& \\ Commerce, Srinivas University, Mangalore - 575001, India. \\ OrcidID: 0000-0002-5878-8844; E-mail: hrganesha@yahoo.co.in \\ ${ }^{2}$ Vice Chancellor, Srinivas University, Mangalore - 575001, India. \\ OrcidID: 0000-0002-4691-8736; E-mail: psaithal@gmail.com \\ ${ }^{3}$ Head of Category Management and Sourcing, Actoserba Active Wholesale Private Limited \\ (Zivame), Bengaluru - 560038, India. \\ OrcidID: 0000-0003-2291-8448; E-mail: spkirubadevi@yahoo.com
}

Area/Section: Business Management.

Type of the Paper: Research Paper.

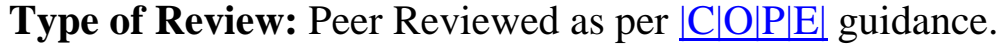

Indexed in: OpenAIRE.

DOI: http://doi.org/10.5281/zenodo.3762937.

Google Scholar Citation: $\underline{\text { IJMTS. }}$

How to Cite this Paper:

Ganesha, H. R., Aithal, P. S., \& Kirubadevi, P. (2020). Changes in Consumer Perspective towards Discount at Brick-and-Mortar Stores owing to Emergence of Online Store Format in India. International Journal of Management, Technology, and Social Sciences (IJMTS),5(1), 43-83.

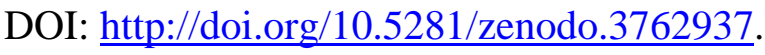

International Journal of Management, Technology, and Social Sciences (IJMTS)

A Refereed International Journal of Srinivas University, India.

(C) With Authors.

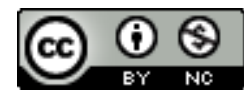

This work is licensed under a Creative Commons Attribution-Non-Commercial 4.0 International License subject to proper citation to the publication source of the work.

Disclaimer: The scholarly papers as reviewed and published by the Srinivas Publications (S.P.), India are the views and opinions of their respective authors and are not the views or opinions of the SP. The SP disclaims of any harm or loss caused due to the published content to any party. 


\title{
Changes in Consumer Perspective towards Discount at Brick-and-Mortar Stores owing to Emergence of Online Store Format in India
}

\author{
H. R. Ganesha ${ }^{1}$, P. S. Aithal ${ }^{2}$, \& P. Kirubadevi ${ }^{3}$ \\ ${ }^{1}$ Chief Executive Officer - Consulting Division, Gramss Retail Trading Private Limited, \\ Bengaluru - 560078, India and Post-Doctoral Research Fellow, College of Management\& \\ Commerce, Srinivas University, Mangalore - 575001, India. \\ OrcidID: 0000-0002-5878-8844; E-mail: hrganesha@yahoo.co.in \\ ${ }^{2}$ Vice Chancellor, Srinivas University, Mangalore - 575001, India. \\ OrcidID: 0000-0002-4691-8736; E-mail: psaithal@gmail.com \\ ${ }^{3}$ Head of Category Management and Sourcing, Actoserba Active Wholesale Private Limited \\ (Zivame), Bengaluru - 560038, India. \\ OrcidID: 0000-0003-2291-8448; E-mail: spkirubadevi@yahoo.com
}

\begin{abstract}
End-of-season sale (EOSS) has been one of the most important long duration sales promotion/discountingevents for brick-and-mortar retailers and consumers in India. But, ever since the online retailing format has emerged in India, consumers now have wider options available for them to buy a product at a discounted price and notably, as online stores in India are following the product discounting as one of the key drivers for consumer acquisition, consumers' perspective towards discount at brick-and-mortar store is expected to have changed.This change in consumers' perspective has put the majority of brick-and-mortar retailers in India into a quandary and they are losing out their market share slowly to online retailers. In this research, authors have attempted to investigate; (a) proof, (b) pattern, (c) magnitude, (d) significance and (e) impact of this change in perspective towards discount across stakeholders and transpired the research outcomes into suggestions to enable brick-and-mortar retailers to design appropriate sales promotions.
\end{abstract}

Keywords: Discount, End-of-season sale, Brick-and-mortar store, Offline store, Physical store, Consumer perspective, Online store, Sales promotion.

\section{INTRODUCTION :}

The e-commerce retailing format undoubtedly making a paradigm shift in the way retailing is done in India. This new retailing format, ecommerce is projected to grow to 62.3 billion US\$ by the year 2023which is at32.34 billion US\$ in the year 2019. Such a significant increase in the market share is attributed mostly to the rapidly increasing penetration of smartphones and internet users. This ongoing change in penetration is projected to increase the total internet user base to 657.8 million by the year 2023which is at 553.7 million as of the year 2019 in India. Share of buyers using ecommerce retailing format in India is expected to increase to 50.03 percent by the year 2020 which is at23.55 percent as of the year 2016 (Statista)[1].The overall market size of the Indian Retail industry which is at 950 billion US\$ in the year 2018 might cross 1.1 trillion US\$ by the year 2020(IBEF)[2].

E-commerce has been able to expand its market consistently in India. Owing to this new retailing format consumers now have the widest product assortment offered to them at discounted prices. 
E-commerce retailing format has probably crosseda key milestone in revolutionizing Indian retail market, and this trend is expected to continue for many more years. As per one IBEF's December 2019 [2] report on Indian retailing, it is noted that the union government of India is also working on various ways to boost consumption in the rural market of India and ecommerce would play an important role in achieving this. The forecast also indicates that ecommerce retailing will be able to capture 7 percent of the overall Indian retail market by 2021.

In such a short period e-commerce retailing format in India reached to around 3 percent of overall Indian retail market. Growth rate is more than double as compared to the brick-and-mortar stores. Available literature indicates to key reasons for this as being capable of building the trust of the consumers in online stores, they have successfully established their brands in the minds of the online shoppers through their 365 days discounts, deals, and low-price strategies. Even though it is very hard to build a sustainable business model using strategies mainly based on price wars, it is inevitable that the Brick-andmortar stores in India will have to ascertain specific strategies head-on to deal with this increasing loss of market share to online stores. Up till the emergence of online stores in India, Brick-and-mortar retailers were following a season and occasion driven sale promotions prominently known as end-of-season sale and festive sale which accounted for close to 40 percent of their annual revenue. But, post the emergence of online stores in India, the majority of brick-and-mortar retailers in India are bewildered with continuous discounts, deals, sale promotion events, coupons being offered by the online stores throughout the year and they are not able to design appropriate sales promotion programmes.

\section{LITERATUREREVIEW :}

We have noted that for many choices of store format was and is one of the important research subjects among many researchers beginning from the 70's of the 20th century. The authors of many of earlier studies - among others: Monroe
\&Guiltinan (1975) [3], Arnold, Oum\&Tigert (1983) [4], Mason, Durand \& Taylor (1983) [5], Keng\& Ehrenberg (1984) [6], Louviere \&Gaeth (1987) [7], Spiggle\& Sewall (1987) [8], Dawson, Bloch \& Ridgway (1990) [9], Burke et al. (1992) [10], Arnold, Handelman \&Tigert (1996) [11], have studied to rationalize store choice using different approaches, models and frameworks with respect to internal and external factors to the consumer such as (a) store attribute, (b) situational factors, (c) consumers' households, (d) consumers' demographics, (e) consumers' shopping patterns, (f) consumers' attitudes toward stores, (g) implied importance and (h) weightage of price levels. It is also noted that most of the above said studies were carried on same store formats (supermarkets and discount stores).

There also exist some studies examining the influence of retail pricing formats on shopping behaviour (Bell, Ho \& Tang, 1998 [12]), often if one store format has in general higher prices than the other one.

Shim et al. (2000) [13], using consumer's shopping behavioural intentions, established the size of three market segments (primarily Internet shopper, product-situation specific crossshopper and primarily store-oriented shopper markets) for both the cognitive and sensory experiential product categories. One of the key recommendations from the researchers was that the retailers and mall developers should understand the greater importance of social influence on online shoppers and crossshoppers, as compared to traditional store shoppers. Perhaps a competitive strategy could be utilized whereby promotions portray aspirational and/or peer members of Internet consumers describing their positive experiences as mall patrons.

Peter and Olson (2002) [14],preferences for retail channel and format choice within a particular channel depend on factors external to the consumer and internal ones. Those preferences are subject to change when important factors as changes in the economy (like economic slowdown, fall in consumers income) and retail industry (development of new sales channels and/or formats) become visible 
for consumers. External factors among others include perceived price level, physical effort to buy, amount of time needed to fulfil shopping tasks - most of the external factors are creating the perceived total cost of buying for the consumer. Among internal factors, there are i.e.: consumer demographics and consumer personality manifesting in decision-making styles and perceived level of cognitive and emotional effort connected with shopping.

Bhatnagar, \& Ratchford (2004) [15]represent an interesting approach but limited to non-durable goods. Exploring fixed and variable costs of shopping, including assumption about consumers preferring to shop at the minimum total cost, and different price levels between formats, they found conditions in which the store format choice would be optimal.

Diwakar Gupta et al. (2006) [16]. The problem of setting prices for clearing retail inventories of fashion goods is a difficult task that is further exacerbated by the fact that markdowns enacted near the end of the selling season have a smaller impact on demand. In the research, they have presented discrete-time models for setting clearance prices in such an environment. When demand is deterministic, researchers compute optimal prices and show that decreasing reservation prices lead to declining optimal prices. When demand is stochastic and arbitrarily correlated across planning periods, researchers obtain bounds on the optimal expected revenue and on optimal prices. Researchers have also developed a heuristic procedure for finding near-optimal prices and test its accuracy through numerical experiments. These experiments revealed new insights for practitioners. For example, the penalty for choosing clearance price once and keeping it unchanged for the remainder of the selling season is found to be small when either the mean reservation prices do not change appreciably over time or when they drop sharply after the first period.

Mokhtarian and Tang (2009, 2011) [17-18], perceived channel characteristics are influencing the choice of channel for both phases of consumer decision making: information search and buying.
Sales promotion techniques are instruments that seek to increase sales of products and brands, usually in a short time (Wierenga\&Soethoudt, 2010) [19], because they act in the consumer's mind as a benefit to him, creating thus consumer behaviour (Yusuf, 2010 [20]). The effectiveness and the importance of sales promotion in the market can be viewed when presenting the segment numbers. According to Teunter (2002) [21], over $20 \%$ of sales of products of some food branches occur through sales promotion activities. In a report quoted by Wierenga and Soethoudt (2010) [19], over 75\% of spending on communication in the nondurable consumer goods segment between 1997 and 2004 in the United States were driven by sales promotion activities, while $25 \%$ were applied in other communication activities.

In addition to market fundamentals, the importance is attested in the scientific field, whose studies have been conducted for several decades. In 1978, Preston, Dwyer, and Rudelius [22] already demonstrated the effect of sales promotion to convince consumers to open a bank account. In that study, it was found that $50 \%$ of the increase in a number of accounts in a bank searched occurred during a promotional campaign. Morerecently, D’Austous and Jacob (2002) [23]demonstrate the efficiency of this promotional tool to influence the computer purchase, while Boschetti (2012) [24] confirmed the positive linkages, promoting the behaviour of purchase of financial services.

As stressed by some authors (D'Austous \& Landreville,2003 [25]; Haans \& Gijsbrechts, 2011 [26]; there is still academic and managerial deficiencies on the deeper knowledge of the relationship of sales promotion with consumer behaviour and their effectiveness for the companies.

Sangvikar B. V. et al. (2012) [27], In this research paper researchers, focussed on studying consumer behaviour across various retail formats available for them to buy products which includes components such as (a) convenience, (b) product assortment, (c) pricing, d) product quality and (e) salesperson services. They concluded that Brick-and-mortar departmental retail format is the most preferred 
one.

Menal Dahiya (2017) [28], due to e-commerce the turnover of offline retailer has reduced which is a warning signal for the enterprise and on the arrival of online shops in the market offline retailers are suffering from the pricing. The researcher has studied the impact of e-commerce sales format on brick-and-mortar selling format across variety of components such as (a) discounts, (b) service types, (c) pricing, (d) product assortment, (e) marketing and promotional capabilities and (f) inventory levels. Dhruv et al (2017) [29]. One of the key components of their organizing framework for 'future of retailing' identified by them was 'visual display and merchandise offer decisions' along with other four components (1) technology and tools to facilitate decision making, (2) consumption and engagement, (3) big data collection and usage and (4) analytics and probability.

Past research carried out in the developed countries where the brick-and-mortar retailers have already gone through a phase of online store formats being made available to consumers and have provided many guidelines to brickand-mortar retailers on various frameworks for them to create promotional strategies to withstand discount strategies of online stores.

We find a gap in the literature whereby we could not find answers for (a) can we implement the recommendations of various researches carried out in developed countries in an Indian context? (b) is there any change in the consumer's perspective toward brick-and-mortar store's famous sales promotional event known as an end-of-season sale? (c) if there a change, what is the magnitude and significance of it in the Indian context? (d) what are the impacts of such changes on other stakeholders across various functions of brick-and-mortar retailing set up such as sales, store operations, category, marketing, supply chain and management/investors. To find answers to these questions we decided to survey all these stakeholders along with consumers, collect empirical data of a brick-and-mortar retailer who has experienced both the phases of pre and post online store emergence and validate all such qualitative findings with actual empirical transactional data to answer our key research questions.

\section{OBJECTIVES :}

Key objectives of this research were to;

(a) Qualitatively:

i. understand retailer perspective towards discounts pre and post online store emergence.

ii. Understand consumer perspective towards discounts pre and post online stores emergence.

(b) Quantitatively:

i. analyze past ten years of empirical data of a select retailer.

ii. determine the correlation among the following variables for pre and post online store emergence independently:

i. discount levels and conversions

ii. discount levels and average transaction sizes

iii. discount levels and average prices

iv. discount levels and store's sales and margin productivity

v. discount levels and store profitability

iii. understand the change in consumer purchase behaviour five years prior to and five years post online store emergence.

(c) Compare qualitative findings (retailer perspectives and consumer perspectives with the quantitative analysis results of the past 10 years of empirical data.

(d) Draw conclusion with respect to changes in consumer perspective towards discounts on;

a. proof of change

b. pattern of change

c. magnitude of change

d. significance and impact of change

\section{METHODOLOGY :}

Stage I: At this stage, primary research was 
conducted in two phases to understand retailers and consumer perspectives towards discounts.

\section{Qualitative phase:}

i. Retailer perspective: The entire population (388 employees) across various functions/department such as (1) management and strategy, (2) marketing and communication, (3) category management, (4) supply chain management, (5) finance and accounts, (6) IT and support functions and (7) human resource department and (8) sales and operations and (9) store sales staff of one select Brick-and-mortar retailer having stores all over India across (a) mall stores, (b) high-street stores,(c) neighborhood stores,(d) tier 1, 2 and 3 cities, (e) offering multiplecategories and multiple-brands at mid to high price positioning catering to pregnant women, new moms, babies, infants and kids up to 8 yearswere interviewed under controlled environment through google sheets to collect information regarding their perspective towards discounts at brickand-mortar stores pre and post emergence of online stores (Research instrument 1).

ii. Consumer perspective: A random sample (2712 customers) of customers of the select Brick-and-mortar retailer pertaining to research instrument 1 , representing customers from stores all over India across (a) mall stores, (b) high-street stores,(c) neighborhood stores,(d) tier 1, 2 and 3 cities, were interviewed under controlled environment through close-ended questions to collect information regarding their perspective towards discounts at brick-and-mortar stores pre and post emergence of online stores (Research instrument 2).

Quantitative phase: Empirical sales data (over eight million transactions)of five years prior and five years post online store emergence in India is collected from the select brick-and-mortar retailer whose employees and customers were surveyed using research instrument 1 and 2(Research instrument 3).

Stage II: In this stage, both qualitative and quantitative findings collected using research instruments 1, 2 and 3 were analysed through data processing and analysis using appropriate statistical methods, tools and software.

Stage III: In this stage, insights and inferences from the research findings were used to propose a way forward for Indian brick-and-mortar retailers to enable them to design appropriate sales promotional programmes to effectively deal with the change in consumer's perspective towards discounts at brick-and-mortar stores.

\section{KEY FINDINGS AND INSIGHTS :}

Retailers strongly believe that, before the emergence of online stores, discounts at a brickand-mortar store were offered basis the age of the inventory that too during specific periods (July and January) widely known as end-ofseason sale (EOSS) which was considered to be a shopping festival. But, post-online stores emergence, the discount has become one of the most important tools for converting walk-ins into bills. Without offering a discount it is practically impossible to convince consumers to buy products at their brick-and-mortar store irrespective of the age of the inventory and the type of sale period owing to which the discounts are now offered to consumers throughout the year to ensure the average transaction values are maintained and possibly stop losing consumers to online store. This significant change in consumers perspective towards discounts is forcing the brick-and-mortar retailer to lose gross margins and in turn store profitability.

Consumers strongly believe that, before the emergence of online stores, discounts at a brickand-mortar store were offered basis the age of the inventory that too during specific periods (July and January) widely known as EOSS which was considered to be a shopping festival for which they used to eagerly await for. But, post-online stores emergence, discounts are available for them throughout the year and hence discount has become one of the most important factors for them to make any buying decisions. It is practically impossible for consumers to buy 
any products at an original price. This significant change in consumers perspective towards discounts is forcing them to not increase their average transaction values per visit to any brick-and-mortar store thereby making the retailer to lose gross margins and in turn store profitability.

Empirical data of ten years of a select brickand-mortar retailer strongly conforms with most of the beliefs of consumers and retailers (obtained through a qualitative survey) on changes in consumer perspective towards discount post emergence of online stores across.
But the data clearly indicates that a) retailer has not followed any strategical way of offering discounts b) retailer is carried away by perceptions/beliefs of store sales staff and consumers, c) discounts have been increased by 2.202 times without any significant improvement in the conversions and average transaction values per consumer. Owing to these changes in consumer perspective towards discount retailer is now making 4.249 times lesser profit as compared to pre-online stores emergence.

Table 1: Except average basket size, average MRP and volume per day per square foot all the other factors in the study match with empirical data and conforms to the belief of retailer and consumer on changes in consumer perspective towards the discount.

Variables

Discount per cent and Bills per day per square foot

Discount per cent and Average basket size

Discount per cent and Average MRP

Discount per cent and Volume per day per square foot

Discount per cent and Average selling price

Discount per cent and Revenue per day per square foot

Discount per cent and Gross margin per day per square foot

Discount per cent and Store profit per day per square foot

Online emergence type and Store profit per day per square foot
Correlation Coefficient

Retailer Consumer Empirical Retailer Consumer Empirical Surve

$-0.62$

$-0.270$

$-0.270$

$-0.389$

$-0.389$

$-0.389$

$-0.286$

$-0.286$

$-0.621$

\section{Survey}

$-0.621$

$-0.940$

$-0.940$

$-0.935$

$-0.935$

$-0.935$

$-1.000$

$-1.000$

$-0.990$

\section{Data}

$-0.135$

0.610

0.662

0.073

$-0.831$

$-0.250$

$-0.715$

$-0.733$

$-0.733$
T Test Sig. (2-tailed)

Suvey

0.000

0.000

0.000

0.000

0.000

0.000

0.000

0.000

0.000

\begin{tabular}{|c|c|}
\hline Survey & Data \\
\hline 0.000 & 0.000 \\
0.000 & 0.000 \\
0.000 & 0.000 \\
0.000 & 0.000 \\
0.000 & 0.000 \\
0.000 & 0.000 \\
0.000 & 0.000 \\
0.000 & 0.000 \\
0.000 & 0.102 \\
\hline
\end{tabular}

Table 2: Empirical data comprising of over eight million transactional records strongly conforms to the belief of retailer and consumer on changes in consumer perspective towards discount.

\begin{tabular}{|l|c|c|c|c|}
\hline & \multicolumn{2}{|c|}{ Correlation } & \multicolumn{2}{c|}{ Sig. (2-tailed) } \\
\hline Variables under empirical data analysis & Pre-Online & Post-Online & Pre-Online & Post-Online \\
\hline Discount per cent and Bills per day per square foot & 0.489 & -0.135 & 0.000 & 0.000 \\
Discount per cent and Average basket size & 0.627 & 0.610 & 0.000 & 0.000 \\
Discount per cent and Average MRP & 0.468 & 0.662 & 0.000 & 0.000 \\
Discount per cent and Volume per day per square foot & 0.707 & 0.073 & 0.000 & 0.000 \\
Discount per cent and Average selling price & -0.682 & -0.831 & 0.000 & 0.000 \\
Discount per cent and Revenue per day per square foot & 0.450 & -0.250 & 0.000 & 0.000 \\
Discount per cent and Gross margin per day per square foot & -0.159 & -0.715 & 0.000 & 0.000 \\
Discount per cent and Store profit per day per square foot & -0.326 & -0.733 & 0.000 & 0.000 \\
Online emergence type and Store profit per day per square foot & -0.326 & -0.733 & 0.000 & 0.102 \\
\hline
\end{tabular}


Store profit per day per square feet

Gross margin per day per square feet

Revenue per day per square feet

Average Selling Price

Volume per day per square feet

Average Basket Value

Average MRP

Average Basket Size

Bills per day per square feet

Discount
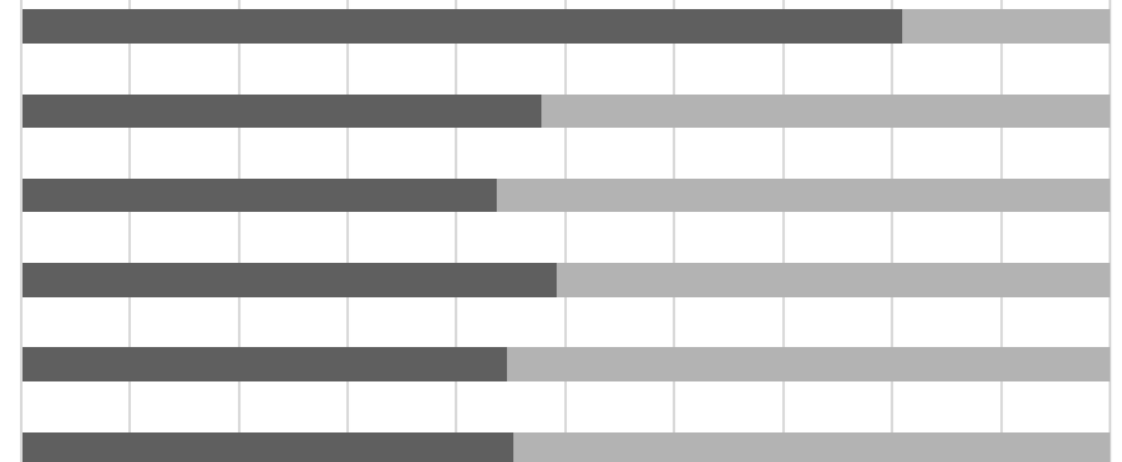

Discoulnt

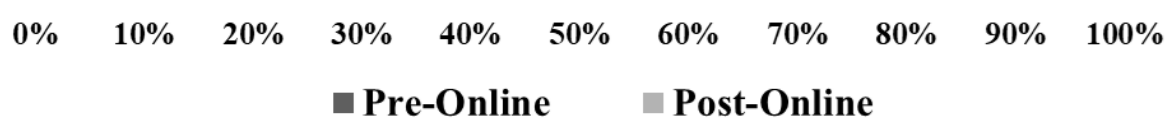

Fig. 1: Empirical data comprising of over eight million transactional records indicate that the discount level has increased significantly post-online store format emergence and has strong negative impact on the brick-and-mortar store profitability.

Table 3: Factor analysis on empirical data comprising of over eight million transactional records indicate that the discount and bills (conversion) components explains the majority of change in store profitability.

\begin{tabular}{|c|c|c|c|c|c|c|}
\hline \multicolumn{7}{|c|}{ Total Variance Explained } \\
\hline \multirow[b]{2}{*}{ Component } & \multicolumn{3}{|c|}{ Initial Eigenvalues } & \multicolumn{3}{|c|}{ Extraction Sums of Squared } \\
\hline & Total & $\begin{array}{c}\% \text { of } \\
\text { Variance }\end{array}$ & $\begin{array}{c}\text { Cumula tive } \\
\%\end{array}$ & Total & $\begin{array}{c}\% \text { of } \\
\text { Variance }\end{array}$ & $\begin{array}{c}\text { Cumulative } \\
\%\end{array}$ \\
\hline Discount per cent & 4.627 & 46.266 & 46.266 & 4.627 & 46.266 & 46.266 \\
\hline Bills per day per square foot & 3.046 & 30.46 & 76.726 & 3.046 & 30.46 & 76.726 \\
\hline Average basket size & 1.684 & 16.844 & 93.57 & 1.684 & 16.844 & 93.57 \\
\hline Average MRP (INR) & 0.578 & 5.782 & 99.352 & & & \\
\hline Average basket value (INR) & 0.034 & 0.343 & 99.695 & & & \\
\hline Volume per day per square foot (INR) & 0.015 & 0.147 & 99.842 & & & \\
\hline Average selling price (INR) & 0.01 & 0.1 & 99.942 & & & \\
\hline Revenue per day per square foot (INR) & 0.004 & 0.037 & 99.978 & & & \\
\hline Gross margin per day per square foot (INR) & 0.001 & 0.014 & 99.992 & & & \\
\hline Store profit per day per square foot (INR) & 0.001 & 0.008 & 100 & & & \\
\hline
\end{tabular}


Table 4: Qualitative comparison of change in perspective towards discount of brick-and-mortar retailer. Bricks-and-mortar retailer pers pective towards discount

Pre-Online

Offering discounts was in our control

Offer discounts based on product age

Increase average basket size

Increase average transaction vahe

Increase in absolute earnings

Attract new consumers

Increase consumer loyalty

Walk-ins coversion was not dependent on discount
Post-Online

Offering discounts is no more in our control

Offer discounts irrespective of product age

Maintain existing basket size

Maintain existing transaction vahe

Protect existing absolute earnings

Retain existing consumers

Minimise consumer shift to online store

Walk-ins coversion is significantly on discount

Table 5: Qualitative comparison of change in perspective towards discount of consumers. Cons umer perspective towards discount

Pre-Online

Discount events are designed for a specific occasion

Let me buy more now

This is my shop and I shall wait for discount events

This is my shop and a neighbourhood store

I shall wait for offers on my favourite brand

Pre-planned shopping for discounted items

Majority of my shopping was at original price
Post-Online

Discounts are available throughout the year

Just buy what is needed

I no more wait for discount events

I can shop online, distance to shop is no more a limitation

Let me try the new brand (discount is available)

Just-in-Time shopping

Majority of my shopping is at discounted price

\section{CONCLUSION :}

With reference to data and comments shown in table 1, 2, 3, 4, 5 and figure 1, It is practically impossible to change consumers perspective towards a discount in favour of brick-and-mortar store as the same is widely influenced by a paradigm shift in the evolution of various modern retailing formats available now to consumers to buy required products. It is evident from this research that brick-and-mortar retailer will no more be able to convert walk-ins into bills unless the discount is one of the key components of their selling proposition to consumers, but possibly retailer can analyse their sales data on a consistent basis to determine ideal levels of discount which can probably gain a competitive edge over online stores on the discount component and arrest such huge degrowth in their store profitability.

\section{SUGGESTIONS TO BRICK-AND- MORTAR RETAILERS :}

Based on this research outcomes, we would like to suggest few do's and don'ts to brick-andmortar retailers to overcome this change in consumer shopping behaviour and perspective towards discount;

Don'ts:

a) flat discounts at the product level,

b) huge variance in the levels of discount during discount and non-discount periods,

c) frequent and continuous spending on any 'above the line' (ATL) advertising activities which are directed towards communicating the discounts,

d) irrelevant discounts,

e) discounting decisions carried away by the online retailer's discounting frameworks and strategies.

Dos:

a) convert most of the product level discounts to a transaction level discounts,

b) offers to be perceived as discounts by the consumers, but they need not be flat discounts on the products, 
c) run promotions which will be able to hold the customer for a longer period of time and perceived by the consumers as a 'great deal',

d) create smart offers which are relevant to consumer life-stage needs

Brick-and-mortar retailers need to clearly understand every other retailer format's key business goal behind offering discounts to consumers. Few may be trying to capture the bigger market share, few may be trying to show exponential growth in the top line to attract more investors, few may be trying to wrap up their business and few may be hoping that all these consumers acquired based on discount as one of their key components of selling proposition are going to be loyal to their store. What is very important is the key business goal of your retailing format and business, clearly understand of your consumers and their needs using both qualitative and quantitative methodologies and make strategies to create your own discounting framework/model to gain a competitive edge over any retailing formats on the discount component.

\section{LIMITATIONS OFRESEARCH :}

The main limitation of this research workis the coverage of the various stakeholders viz., consumers and retailers in understanding their perspectives towards discount pre and post online store format emergence. This might limit the generalizability of the research findings to other set of retailers and consumers. The second limitation would be the empirical validation is restricted to one retail format i.e., multi brand and multi category baby care stores in India and hence the generalizability of the findings and suggestions to other retail formats. However, it provides significant input regarding the ways to utilise these findings as all the qualitative research findings have been validated with actual empirical transactional data.

\section{SCOPE FOR FURTHER RESEARCH :}

It is recommended that this research can further be extended to derive an ideal discounting framework/model for brick-and-mortar retailers to enable them to design appropriate sales promotional programmes to effectively deal with the change in consumer's perspective towards the discount.

\section{REFERENCES :}

[1] https://www.statista.com/statistics/289770 /e-commerce-revenue-forecast-in-india/. Referred on $15^{\text {th }}$ March 2020.

[2] https://www.ibef.org/industry/retailindia.aspx. Referred on $15^{\text {th }}$ March 2020.

[3] Monroe, K. B., \&Guiltinan, J. P. (1975). A path-analytic exploration of retail patronage influences. Journal of Consumer Research, 2(1), 19- 28.

[4] Arnold, S. J., Oum, T. H., \&Tigert, D. J. (1983). Determinant attributes in retail patronage: Seasonal temporal, regionaland international comparisons. Journal of Marketing Research, 20(2), 149-157.

[5] Mason, J. B., Durand, R. M., and Taylor, J. L. (1983). Retail patronage: A causal analysis of antecedent factors. In W. Darden, \& R. Lusch (Eds.), Patronage behavior and retail management (pp. 339-352). New York: North-Holland.

[6] Keng, K. A., \& Ehrenberg, A. S. C. (1984). Patterns of store choice. Journal of Marketing Research, 21(4), 399-409.

[7] Louviere, J. J., \&Gaeth, G. J. (1987). Decomposing the determinants of retail facility choice using the method of hierarchical and international comparisons. Journal of Marketing Research, 63(1), 149-157. 942.

[8] Spiggle, S., \& Sewall, M. A. (1987). A choice set model of retail selection. Journal of Marketing, 51(2), 97-111.

[9] Dawson, S., Bloch, P. H., \&Ridway, N. M. (1990). Shopping motives, emotional states and retail outcomes. Journal of Retailing, 66(4), 408-427. 
[10] Burke, R., Bari, R., Harlam, A., Kahn, B. E., \&Lodish, L. M. (1992). Comparing dynamic consumer choice in real and computer- simulated environments. Journal of Consumer Research, 19(1), 71-82.

[11] Arnold, S. J., Handelman, J., \&Tigert, D. J. (1996). Organizational legitimacy and retail store patronage. Journal of Business Research, 35(3), 229- 239.

[12] Bell, D. R., Ho, T., \& Tang, C. S. (1998). Determining where to shop: Fixed and variable costs of shopping. Journal of Marketing Research, 35(3), 352- 369 .

[13] Shim, Soyeon\&Eastlick, M.A. \&Lotz, Sherry. (2000). Assessing the impact of internet shopping on store shopping among mall shoppers and internet users. Journal of Shopping Center Research, 7. 7-43.

[14] Peter J.P., Olson J.C. (2002), Consumer Behavior and Marketing Strategy, Homewood, IL: Irwin - McGrawHill,

[15] Bhatnagar, A., Ratchford, B. T. (2004). A model of retail format competition for non-durable goods. International Journal of Research in Marketing, 21(1), 39-59.

[16] Diwakar Gupta, Artur V. Hill, Tatiana Bouzdine-Chameeva. (2006). A pricing model for clearing end-of-season retail inventory. European Journal for Operational Research, 170, 518-540.

[17] Mokhtarian P.L. and Tang W. L. (2009), Accounting for Taste Heterogeneity in Purchase Channel Intention Modeling: An Example from Northern California for Book Purchases, Journal of Choice Modelling, 2(2), 148-172.

[18] Mokhtarian P.L. and Tang W. L. (2011), Trivariateprobit models of prepurchase/purchase shopping channel choice: clothing purchases in northern California, $\quad$ Paper presented
atInternational Choice Modelling Conference 2011, Oulton Hall (UK) 46July2011,

http://www.icmconference.org.uk/index. php/icmc/ICMC2011/paper/view/426/11 9.

[19] Wierenga, B., \&Soethoudt, H. (2010). Sales promotions and channel coordination. Original Empirical Research, 38(3), 383-397. DOI:10.1007/s11747-009-0161-1.

[20] Yusuf, J. B. (2010). Ethical implications of sales promotion in Ghana: Islamic perspective. Journal of Islamic Marketing, 1(3), 220-230. DOI:10.1108/17590831011082400.

[21] Teunter, L.H. (2002). Analysis of sales promotion effects on household purchasing behavior. ERIM PhD Research Series in Management, Erasmus University Rotterdam, p. 262272.

[22] Preston, R. H., Dwyer, F. R., \& Rudelius, W. (1978). The effectiveness of bank premiums. The Journal of Marketing, 42(3), 96-101. doi:10.2307/1250542.

[23] D’Astous, A., \& Jacob, I. (2002). Understanding consumer reactions to premium-based promotional offers. European Journal of Marketing. 36(11/12), 1270-1286.

[24] Boschetti, R. B. (2012). Promoção de vendasnãomonetária seusefeitosnaintenção de compra e naescolha da marca de serviçosfinanceiros.Dissertação (Mestrado) PontificaUniversidadeCatólica do Rio Grande do Sul, Porto Alegre, RS, Brasil.

[25] D’Astous, A., \& Landreville, L. (2003). An experimental investigation of factors affecting consumers' perceptions of sales promotions.European Journal of 
Marketing, $\quad 37(11 / 12), \quad$ 1746-1761. DOI:10.1108/03090560310495447.

[26] Haans, H., \& Gijsbrechts, E. (2011). One-deal-fits-all? On category sales promotion effectiveness in smaller versus larger supermarkets.Journal of Retailing, 87(4), 427-443. DOI: 10.1016/j.jretai.2011.05.001.

[27] Sangvikar, B. V. \& Hemant, J. (2012). A study of consumer purchase behavior in organized retail outlets.Journal of Business \& Retail Management Research, 7(1), 39 - 47.

[28] Menal Dahiya (2017). Study on ECommerce and it's Impacts on Market and Retailers in India.Advances in Computational Sciences and Technology, 10(5), 1495-1500.

[29] Dhruv Grewal, Anne L. Roggeveen, Jens Nordfält (2017). Future of Retailing.Journal of Retailing, 93(1), 16. 


\section{Appendix}

\section{Research Instrument 1-Retailer perspective}

Research Instrument 1-Retaller perspective

QI. Help me know you better.

Name

Location

Region

Industry / Domain

Role

Age

Gender

Marital status

Education level

Work experience

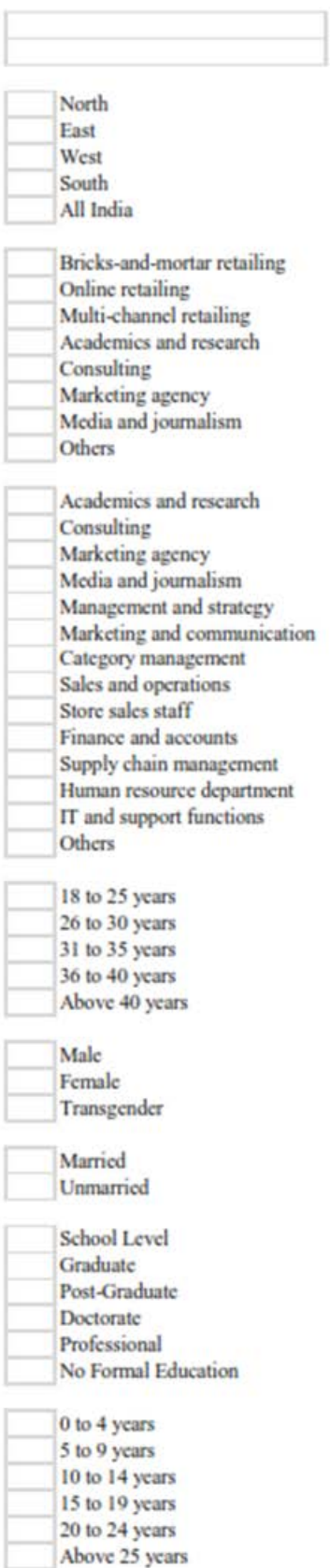




\section{Research Instrument 1 - Retaller perspective}

Q2. When do you think online stores came to lime light in India?

Q3. Prior to online stores boom, major discounts were given only during EOSS.

2000 to 2004

2005 to 2009

2010 to 2014

2015 onwards

Don't remember

Q4. Prior to online stores boom, majority of consumers were not expecting discounts during non EOSS periods.

Strongly disagree

Disagree

Neutral

Agree

Strongly agree

Strongly disagree

Disagree

Neutral

Agree

Strongly agree

Q5. Prior to online stores boom, EOSS event was conducted to liquidate the old inventory/stock.

Strongly disagree

Disagree

Neutral

Agree

Strongly agree

Q6. Prior to online stores boom, EOSS event was conducted to increase the transaction volume and value per consumer.

Strongly disagree

Disagree

Neutral

Agree

Strongly agree

Q7. Prior to online stores boom, EOSS event was conducted to encourage consumer to buy more than usual.

Strongly disagree

Disagree

Neutral

Agree

Strongly agrec

Q8. Prior to online stores boom, during EOSS, store used to earn same margin values in spite of discount as the sales volume was higher than usual.

Strongly disagree

Disagree

Neutral

Agree

Strongly agree

Q9. Prior to online stores boom, EOSS event was conducted twice a year, one in July (31 days) and one in January (31 days).

Strongly disagree

Disagree

Neutral

Agree

Strongly agree

Q10. Prior to online stores boom, EOSS event was perceived as a shopping festival by the company and consumers.

Strongly disagree

Disagree

Neutral

Agree

Strongly agree

Q11. Prior to the stores boom, it was very difficult to convert majority of the walk-ins to bills without discounts.

Strongly disagree

Disagree

Neutral

Agree

Strongly agree 
Research Instrument 1 - Retaller perspective

Q12. Post the online stores boom, discounts are given during non-EOSS periods also.

Strongly disagree

Disagree

Neutral

Agree

Strongly agree

Q13. Post the online stores boom, majority of consumers are expecting discounts throughout the year.

Strongly disagree

Disagree

Neutral

Agree

Strongly agree

Q14. Post the online stores boom, discounts are given irrespective of inventory/stock's age.

Strongly disagree

Disagree

Neutral

Agree

Strongly agree

Q15. Post the online stores boom, EOSS event is conducted to protect the usual transaction volume and value per consumer.

Strongly disagrec

Disagree

Neutral

Agree

Strongly agree

Q16. Post the online stores boom, EOSS event is conducted to encourage consumer to buy from bricks-and-mortar stores and discourage them to shift to online.

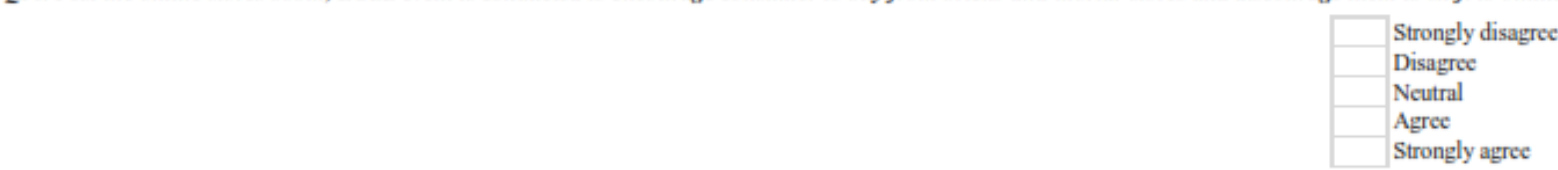

Q17. Post the online stores boom, during EOSS, store loses margin value as in spite of heavy discounts the sales volume is not higher than usual.

Strongly disagree

Disagree

Neutral

Agree

Strongly agree

Q18. Post the online stores boom, EOSS event is conducted once in every three months.

Strongly disagree

Disagree

Neutral

Agree

Strongly agree

Q19. Post the online stores boom, EOSS event is no more perceived as a shopping festival by the company and consumers.

Strongly disagree

Disagree

Neutral

Agree

Strongly agree

Q20. Post the online stores boom, it is becoming very difficult to convert majority of the walk-ins to bills without discounts. 


\section{Research Instrument 2-Consumer perspective}

Research Instrument 2 - Consumer perspective

Q1. Help me know you better.
Name
Location
Region

Shopping preference

Occupation

Age

Gender

Marital status

Education level

Shopping experience

Monthly family income

Are you new to this store or is it your repeat visit?
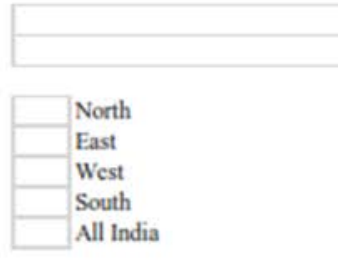

Only physical store Only online store Both online and physical sto Depends on product Others

House wife Employed Business Employed Others

20 to 25 years 26 to 30 years 31 to 35 years 36 to 40 years Above 40 years

Male Female

Transgender

Married

Unmarried

School Level Graduate Post-Graduate Professional No Formal Education

0 to 4 ycars 5 to 9 years 10 to 14 years 15 to 19 years 20 to 24 years Above 25 years

Bclow Rs. 25,000 Rs. 26,000 to Rs. 50,000 Rs. 51,000 to Rs. 75,000 Rs. 76,000 to Rs. $1,00,000$ Above Rs. $1,00,000$

Repeat 


\section{Research Instrument 2 - Consumer perspective}

Q3. Prior to online stores boom, major discounts were given only during EOSS in physical stores.

Strongly disagree

Disagree

Neutral

Agree

Strongly agree

Q4. Prior to online stores boom, majority of time I was not expecting discounts during non EOSS periods.

trongly disagree

Disagree

Neutral

Agree

Strongly agrec

Q5. Prior to online stores boom, heavy discounts were offered only on old stocks during EOSS.

Strongly disagree Disagree

Neutral

Agree

Strongly agree

Q6. Prior to online stores boom, I used to buy more during EOSS than usual.

Strongly disagree

Disagree

Neutral

Agree

Strongly agrec

Q7. Prior to online stores boom, during EOSS it was highly encouraging to buy more than usual.

Strongly disagree

Disagree

Neutral

Agree

Strongly agrec

Q8. Prior to online stores boom, during EOSS, I could buy more for less.

Strongly disagree

Disagree

Neutral

Agree

Strongly agree

Q9. Prior to online stores boom, I used to eagerly wait for July and January months as EOSS would start.

Strongly disagree

Disagree

Neutral

Agree

Strongly agree

Q10. Prior to online stores boom, EOSS event was a shopping festival.

Strongly disagree

Disagree

Neutral

Agree

Strongly agree

Q11. Prior to the online stores boom, it is was not difficult to buy products at full price at any physical stores.

Strongly disagree

Disagree

Neutral

Agree

Strongly agree

Q12. Post the online stores boom, I get discounts during non-EOSS periods also.

Strongly disagree

Neutral

Agree

Strongly agree 


\section{Research Instrument 2 - Consumer perspective}

Q13. Post the online stores boom, I expect physical stores to match online discounts for the same product throughout the year.

Strongly disagree

Disagree

Neutral

Agree

Strongly agree

Q14. Post the online stores boom, discounts are also offered on new stocks in physical stores.

Strongly disagree Disagree

Neutral

Agree

Strongly agree

Q15. Post the online stores boom, I need not to wait for an EOSS event to buy more.

Strongly disagree

Disagree

Neutral

Agree

Strongly agree

Q16. Post the online stores boom, I usually threaten the physical store staff that I will buy from online store if they do not offer me better discounts.

\begin{tabular}{|l|l|}
\hline & Strongly disagree \\
Disagrec \\
\hline Neutral \\
Agree \\
\hline Strongly agree \\
\hline
\end{tabular}

Q17. Post the online stores boom, during EOSS, I need not to buy more than usual as discounts are now available throughout the year online.

Strongly disagrec

Disagree

Neutral

Agree

Strongly agree

Q18. Post the online stores boom, EOSS event is conducted more times than earlier.

Strongly disagree

Disagree

Neutral

Agree

Strongly agree

Q19. Post the online stores boom, EOSS event is no more a most awaited shopping festival for me.

Strongly disagrec Disagree

Neutral

Agree

Strongly agree

Q20. Post the online stores boom, it is very difficult to buy products at full price at any physical stores.

Strongly disagree

Disagree

Neutral

Agree

Strongly agree 


\section{Research Instrument 3 - Empirical data}

Collect actual sales data from a retailer;

1. Existed pre and post emergence of online stores boom in India.

2. Year 2009 to 2019.

3. Covering both pre and post online stores emergence periods.

4. Over eight million transactional data extracted.

\begin{tabular}{|c|c|c|c|c|c|}
\hline \multicolumn{6}{|c|}{ Respondents Region } \\
\hline & & Frequency & Percent & $\begin{array}{c}\text { Valid } \\
\text { Percent }\end{array}$ & $\begin{array}{c}\text { Cumulative } \\
\text { Percent }\end{array}$ \\
\hline \multirow{6}{*}{ Valid } & North & 110 & 28.4 & 28.4 & 28.4 \\
\hline & East & 13 & 3.4 & 3.4 & 31.8 \\
\hline & West & 33 & 8.5 & 8.5 & 40.3 \\
\hline & South & 197 & 50.9 & 50.9 & 91.2 \\
\hline & All India & 34 & 8.8 & 8.8 & 100 \\
\hline & Total & 387 & 100 & 100 & \\
\hline \multicolumn{6}{|c|}{ Industry / Domain } \\
\hline & & Frequency & Percent & $\begin{array}{c}\text { Valid } \\
\text { Percent }\end{array}$ & $\begin{array}{c}\text { Cumulative } \\
\text { Percent }\end{array}$ \\
\hline Valid & $\begin{array}{l}\text { Bricks-and- } \\
\text { mortar retailing }\end{array}$ & 387 & 100 & 100 & 100 \\
\hline
\end{tabular}

\begin{tabular}{|c|c|c|c|c|c|}
\hline \multicolumn{6}{|c|}{ Role } \\
\hline & & Frequency & Percent & $\begin{array}{c}\text { Valid } \\
\text { Percent }\end{array}$ & $\begin{array}{c}\text { Cumulative } \\
\text { Percent }\end{array}$ \\
\hline \multirow{10}{*}{ Valid } & Management and strategy & 2 & 0.5 & 0.5 & 0.5 \\
\hline & Marketing and communication & 6 & 1.6 & 1.6 & 2.1 \\
\hline & Category management & 10 & 2.6 & 2.6 & 4.7 \\
\hline & Sales and operations & 85 & 22 & 22 & 26.6 \\
\hline & Store sales staff & 268 & 69.3 & 69.3 & 95.9 \\
\hline & Finance and accounts & 2 & 0.5 & 0.5 & 96.4 \\
\hline & Supply chain management & 4 & 1 & 1 & 97.4 \\
\hline & Human resource department & 5 & 1.3 & 1.3 & 98.7 \\
\hline & IT and support functions & 5 & 1.3 & 1.3 & 100 \\
\hline & Total & 387 & 100 & 100 & \\
\hline
\end{tabular}

Age Group in Years

$\begin{array}{rlrrrr} & \text { Frequency } & \text { Percent } & \text { Valid Percent } & \text { Cumulative } \\ & 18 \text { to } 25 \text { years } & 152 & 39.3 & 39.3 & 39.3 \\ \text { Valid } & 26 \text { to } 30 \text { years } & 97 & 25.1 & 25.1 & 64.3 \\ 31 \text { to } 35 \text { years } & 83 & 21.4 & 21.4 & 85.8 \\ & 36 \text { to } 40 \text { years } & 38 & 9.8 & 9.8 & 95.6 \\ \text { Above } 40 \text { years } & 17 & 4.4 & 4.4 & 100 \\ & \text { Total } & 387 & 100 & 100 & \end{array}$




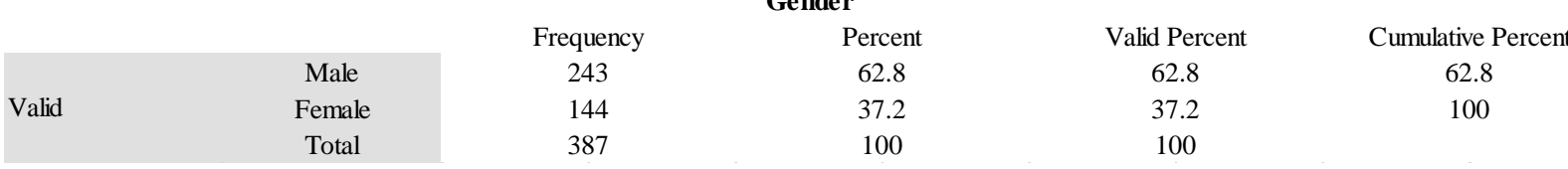

Marital Status

$\begin{array}{cccc}\text { Frequency } & \text { Percent } & \text { Valid } & \text { Cumulative } \\ 265 & 68.5 & 68.5 & 68.5 \\ 122 & 31.5 & 31.5 & 100 \\ 387 & 100 & 100 & \end{array}$

\section{Education Level}

$\begin{array}{cccccc} & & \text { Frequency } & \text { Percent } & \text { Valid } & \text { Cumulative } \\ & \text { School Level } & 269 & 69.5 & 69.5 & 69.5 \\ \text { Valid } & \text { Graduate } & 98 & 25.3 & 25.3 & 94.8 \\ & \text { Post-Graduate } & 19 & 4.9 & 4.9 & 99.7 \\ & \text { Doctorate } & 1 & 0.3 & 0.3 & 100 \\ & \text { Total } & 387 & 100 & 100 & \end{array}$

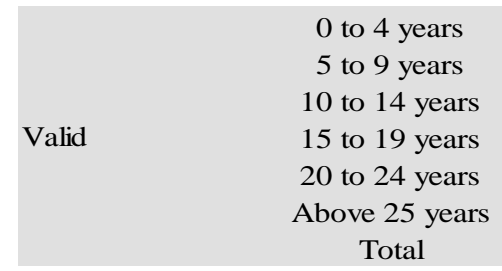

Work Experience in Years

$\begin{array}{cc}\text { Frequency } & \text { Percent } \\ 68 & 17.6 \\ 128 & 33.1 \\ 91 & 23.5 \\ 67 & 17.3 \\ 21 & 5.4 \\ 12 & 3.1 \\ 387 & 100\end{array}$

$\begin{array}{cc}\text { Valid Percent } & \text { Cumulative Percent } \\ 17.6 & 17.6 \\ 33.1 & 50.6 \\ 23.5 & 74.2 \\ 17.3 & 91.5 \\ 5.4 & 96.9 \\ 3.1 & 100 \\ 100 & \end{array}$

Q2. When do you think online stores came to limelight in India?

\begin{tabular}{cccccc} 
& & Frequency & Percent & Valid Percent & Cumulative Per \\
& 2000 to 2004 & 1 & 0.3 & 0.3 & 0.3 \\
\multirow{3}{*}{ Valid } & 2005 to 2009 & 15 & 3.9 & 3.9 & 4.1 \\
& 2010 to 2014 & 356 & 92 & 3.9 & 96.1 \\
& 2015 onwards & 15 & 3.9 & 100 & 100
\end{tabular}

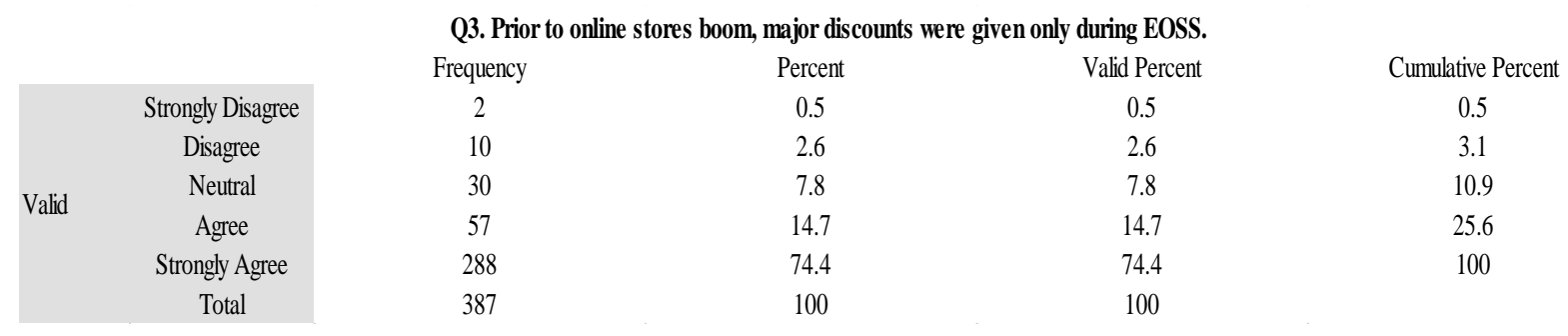

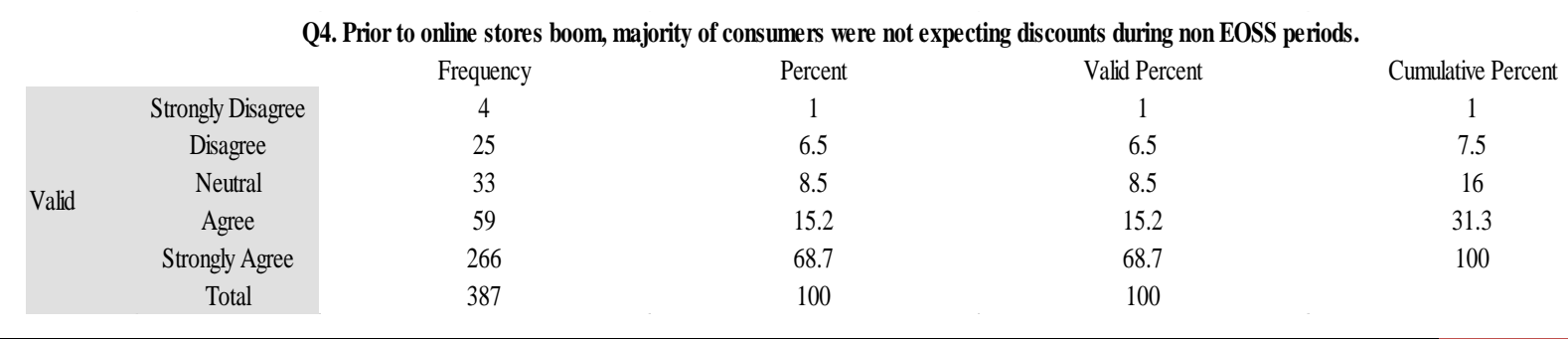

H. R. Ganesha, et al, (2020); www.srinivaspublication.com 
Q5. Prior to online stores boom, EOSS event was conducted to liquidate the old inventory/stock.

$\begin{array}{cc} & \text { Strongly Disagree } \\ \text { Disagree } \\ \text { Valid } & \text { Neutral } \\ & \text { Agree } \\ & \text { Strongly Agree } \\ & \text { Total }\end{array}$

$\begin{array}{cc}\text { Frequency } & \text { Percent } \\ 8 & 2.1 \\ 8 & 2.1 \\ 59 & 15.2 \\ 38 & 9.8 \\ 274 & 70.8 \\ 387 & 100\end{array}$

Valid Percent

$\begin{array}{cc}2.1 & 2.1 \\ 2.1 & 4.1 \\ 15.2 & 19.4 \\ 9.8 & 29.2 \\ 70.8 & 100 \\ 100 & \end{array}$

Q6. Prior to online stores boom, EOSS event was conducted to increase the transaction volume and value per consumer.

$\begin{array}{cccccc} & & \text { Frequency } & \text { Percent } & \text { Valid Percent } & 0.8 \\ \text { Valid } & \text { Strongly Disagree } & 3 & 0.8 & 2.1 & 0.8 \\ \text { Disagree } & 8 & 2.1 & 7.8 & 2.8 \\ & \text { Neutral } & 30 & 7.8 & 12.9 & 76.5 \\ & \text { Agree } & 50 & 76.9 & 23.5 \\ & \text { Strongly Agree } & 296 & 100 & 100\end{array}$

Q7. Prior to online stores boom, EOSS event was conducted to encourage consumer to buy more than usual.

\begin{tabular}{|c|c|c|c|c|c|}
\hline & & Frequency & Percent & Valid Percent & Cumulative Percent \\
\hline \multirow{6}{*}{ Valid } & Strongly Disagree & 2 & 0.5 & 0.5 & 0.5 \\
\hline & Disagree & 7 & 1.8 & 1.8 & 2.3 \\
\hline & Neutral & 32 & 8.3 & 8.3 & 10.6 \\
\hline & Agree & 69 & 17.8 & 17.8 & 28.4 \\
\hline & Strongly Agree & 277 & 71.6 & 71.6 & 100 \\
\hline & Total & 387 & 100 & 100 & \\
\hline
\end{tabular}

Q8. Prior to online stores boom, during EOSS, store used to earn same margin values in spite of discount as the sales volume was higher than usual.

$\begin{array}{cccccc} & & \text { Frequency } & \text { Percent } & \text { Valid Percent } & 0.3 \\ \text { Strongly Disagree } & 1 & 0.3 & 3.6 & 0.3 \\ \text { Valid } & \text { Disagree } & 14 & 3.6 & 6.5 & 3.9 \\ & \text { Neutral } & 25 & 6.5 & 18.6 & 2.3 \\ & \text { Agree } & 72 & 71.1 & 71.1 & 10.3 \\ & \text { Strongly Agree } & 275 & 100 & 100\end{array}$

Q9. Prior to online stores boom, EOSS event was conducted twice a year, one in July (31 days) and one in January (31 days).

\begin{tabular}{cccccc} 
& & Frequency & Percent & Valid Percent & 1.6 \\
\multirow{4}{*}{ Valid } & Disagree & 6 & 1.6 & 1.6 & 1.1 \\
& Neutral & 43 & 11.1 & 22.2 & 3.7 \\
& Agree & 86 & 22.2 & 65.1 & 12.7 \\
& Strongly Agree & 252 & 65.1 & 100
\end{tabular}

Q10. Prior to online stores boom, EOSS event was perceived as a shopping festival by the company and consumers.

\begin{tabular}{|c|c|c|c|c|c|}
\hline & & Frequency & Percent & Valid Percent & Cumulative Perce \\
\hline \multirow{5}{*}{ Valid } & Disagree & 3 & 0.8 & 0.8 & 0.8 \\
\hline & Neutral & 38 & 9.8 & 9.8 & 10.6 \\
\hline & Agree & 87 & 22.5 & 22.5 & 33.1 \\
\hline & Strongly Agree & 259 & 66.9 & 66.9 & 100 \\
\hline & Total & 387 & 100 & 100 & \\
\hline
\end{tabular}

Q11. Prior to the online stores boom, it was very difficult to convert majority of the walk-ins to bills without discount.

\begin{tabular}{|c|c|c|c|c|c|}
\hline & \\
\hline & & Frequency & Percent & Valid Percent & Cumulative Percent \\
\hline \multirow{6}{*}{ Valid } & Strongly Disagree & 283 & 73.1 & 73.1 & 73.1 \\
\hline & Disagree & 48 & 12.4 & 12.4 & 85.5 \\
\hline & Neutral & 23 & 5.9 & 5.9 & 91.5 \\
\hline & Agree & 20 & 5.2 & 5.2 & 96.6 \\
\hline & Strongly Agree & 13 & 3.4 & 3.4 & 100 \\
\hline & Total & 387 & 100 & 100 & \\
\hline
\end{tabular}

$\begin{array}{lccc}\begin{array}{l}\text { Q12. Post the online stores boom, discounts are given during non-EOSS periods also. } \\ \text { Frequency }\end{array} & \text { Valid Percent } & \text { Cumulative Percent } \\ 262 & 67.7 & 67.7 & 67.7 \\ 114 & 29.5 & 29.5 & 97.2 \\ 9 & 2.3 & 2.3 & 99.5 \\ 2 & 0.5 & 0.5 & 100 \\ 387 & 100 & 100 & \end{array}$


Q13. Post the online stores boom, majority of consumers are expecting discounts throughout the year.

Strongly Agree
Agree
Neutral
Valid $\quad$ Disagree
Strongly Disagree
Total

$\begin{array}{cccc}\text { Frequency } & \text { Percent } & \text { Valid Percent } & \text { Cumulative Percent } \\ 259 & 66.9 & 66.9 & 66.9 \\ 92 & 23.8 & 23.8 & 90.7 \\ 15 & 3.9 & 3.9 & 94.6 \\ 18 & 4.7 & 4.7 & 99.2 \\ 3 & 0.8 & 0.8 & 100 \\ 387 & 100 & 100 & \end{array}$

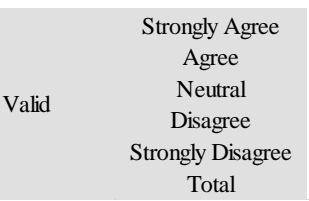

Q14. Post the online stores boom, discounts are given irrespective of inventory/stock's age.

$\begin{array}{cccc}\text { Frequency } & \text { Percent } & \text { Valid Percent } & \text { Cumulative Percent } \\ 220 & 56.8 & 56.8 & 56.8 \\ 137 & 35.4 & 35.4 & 92.2 \\ 10 & 2.6 & 2.6 & 94.8 \\ 18 & 4.7 & 4.7 & 99.5 \\ 2 & 0.5 & 0.5 & 100 \\ 387 & 100 & 100 & \end{array}$

Q15. Post the online stores boom, EOSS event is conducted to protect the usual transaction volume and value per consumer.

\begin{tabular}{|c|c|c|c|c|c|}
\hline & & Frequency & Percent & Valid Percent & Cumulative Percent \\
\hline \multirow{6}{*}{ Valid } & Strongly Agree & 213 & 55 & 55 & 55 \\
\hline & Agree & 153 & 39.5 & 39.5 & 94.6 \\
\hline & Neutral & 17 & 4.4 & 4.4 & 99 \\
\hline & Disagree & 3 & 0.8 & 0.8 & 99.7 \\
\hline & Strongly Disagree & 1 & 0.3 & 0.3 & 100 \\
\hline & Total & 387 & 100 & 100 & \\
\hline
\end{tabular}

Q16. Post the online stores boom, EOSS event is conducted to encourage consumer to buy from bricks-and-mortar stores and discourage them to shift to online.

\begin{tabular}{|c|c|c|c|c|c|}
\hline & & Frequency & Percent & Valid Percent & Cumulative Percent \\
\hline \multirow{5}{*}{ Valid } & Strongly Agree & 227 & 58.7 & 58.7 & 58.7 \\
\hline & Agree & 115 & 29.7 & 29.7 & 88.4 \\
\hline & Neutral & 26 & 6.7 & 6.7 & 95.1 \\
\hline & Disagree & 19 & 4.9 & 4.9 & 100 \\
\hline & Total & 387 & 100 & 100 & \\
\hline
\end{tabular}

Q17. Post the online stores boom, during EOSS, store loses margin value as in spite of heavy discounts the sales volume is not higher than usual.

\begin{tabular}{|c|c|c|c|c|c|}
\hline & & Frequency & Percent & Valid Percent & Cumulative Percent \\
\hline & Strongly Agree & 223 & 57.6 & 57.6 & 57.6 \\
\hline & Agree & 117 & 30.2 & 30.2 & 87.9 \\
\hline Valid & Neutral & 25 & 6.5 & 6.5 & 94.3 \\
\hline valla & Disagree & 21 & 5.4 & 5.4 & 99.7 \\
\hline & Strongly Disagree & 1 & 0.3 & 0.3 & 100 \\
\hline & Total & 387 & 100 & 100 & \\
\hline
\end{tabular}

\begin{tabular}{cccccc}
\multicolumn{1}{c}{} & & Frequency & \multicolumn{2}{c}{ Calid Percent } & 63.8 \\
Valid & Strongly Agree & 247 & 63.8 & 33.1 & 63.8 \\
& Agree & 128 & 33.1 & 1.6 & 96.9 \\
& Neutral & 6 & 1.6 & 1.6 & 1.6 \\
& Disagree & 6 & 100 & 100
\end{tabular}

Q19. Post the online stores boom, EOSS event is no more perceived as a shopping festival by the company and consumers.

\begin{tabular}{cccccc} 
& & Frequency & Percent & \multicolumn{2}{c}{ Valid Percent } \\
\multirow{4}{*}{ Valid } & Strongly Agree & 288 & 74.4 & 74.4 & 10.6 \\
& Agree & 41 & 10.6 & 12.4 & 85 \\
& Neutral & 48 & 12.4 & 2.6 & 2.6 \\
& Disagree & 10 & 100 & 100 & 100
\end{tabular}

Q20. Post the online stores boom, it is becoming very difficult to convert majority of the walk-ins to bills.

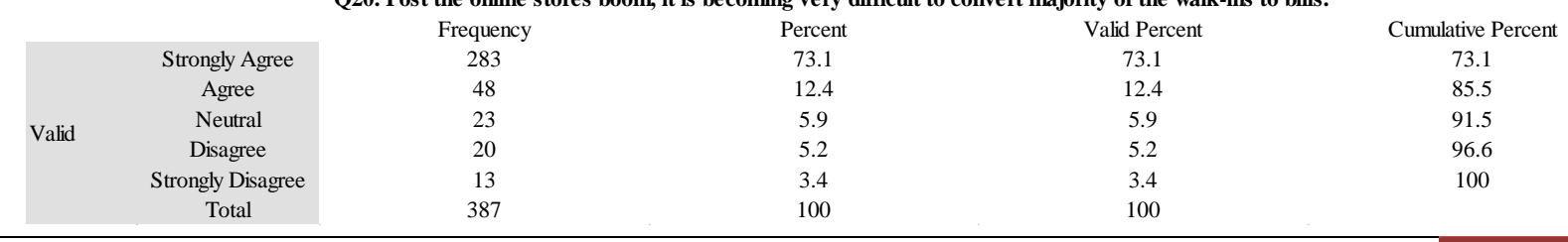

H. R. Ganesha, et al, (2020); www.srinivaspublication.com 
Average scores for pre-online emergence questions Frequency Percent Valid Percent

Cumulative Percent

$\begin{array}{cc} & 2.25 \\ 2.38 \\ 2.5 \\ 2.63 \\ 2.75 \\ 2.88 \\ 3 \\ 3.13 \\ 3.25 \\ 3.38 \\ 3.5 \\ 3.63 \\ 3.75 \\ 3.88 \\ 4 \\ 4.13 \\ 4.25 \\ 4.38 \\ 4.5 \\ 4.63 \\ 4.75 \\ 4.88 \\ 5 \\ \text { Totid } \\ \\ \end{array}$

0.3

0.8

0.5

0.3

0.8

0.5

0.3

1

2.3

0.3

1.8

0.8

3.4

1.8

1.8

3.1

3.1

5.9

7.5

11.4

7.2

8.5

36.7

100
0.3

0.8

0.5

0.3

0.8

0.5

0.3

1

2.3

0.3

1.8

0.8

3.4

1.8

1.8

3.1

3.1

5.9

7.5

11.4

7.2

8.5

36.7

100
0.3

1

1.6

1.8

2.6

3.1

3.4

4.4

6.7

7

8.8

9.6

12.9

14.7

16.5

19.6

22.7

28.7

36.2

47.5

54.8

63.3

100

Average scores for post-online emergence questions

$\begin{array}{cccccc} & & \text { Frequency } & \text { Percent } & \text { Valid Percent } & \text { Cumulative } \\ 1 & 91 & 23.5 & 23.5 & 23.5 \\ 1.11 & 58 & 15 & 15 & 38.5 \\ 1.22 & 32 & 8.3 & 8.3 & 46.8 \\ 1.33 & 32 & 8.3 & 8.3 & 55 \\ 1.44 & 10 & 2.6 & 2.6 & 57.6 \\ 1.56 & 11 & 2.8 & 2.8 & 60.5 \\ 1.67 & 25 & 6.5 & 6.5 & 66.9 \\ 1.78 & 26 & 6.7 & 6.7 & 73.6 \\ & 1.89 & 26 & 6.7 & 6.7 & 80.4 \\ 2 & 18 & 4.7 & 4.7 & 85 \\ 2.11 & 16 & 4.1 & 4.1 & 89.1 \\ 2.22 & 5 & 1.3 & 1.3 & 90.4 \\ 2.33 & 6 & 1.6 & 1.6 & 92 \\ 2.44 & 12 & 3.1 & 3.1 & 95.1 \\ 2.56 & 12 & 3.1 & 3.1 & 98.2 \\ 2.67 & 5 & 1.3 & 1.3 & 99.5 \\ 2.78 & 1 & 0.3 & 0.3 & 99.7 \\ 2.89 & 1 & 0.3 & 0.3 & 100 \\ & \text { Total } & 387 & 100 & 100 & \end{array}$

H. R. Ganesha, et al, (2020); www.srinivaspublication.com 


\section{Correlations}

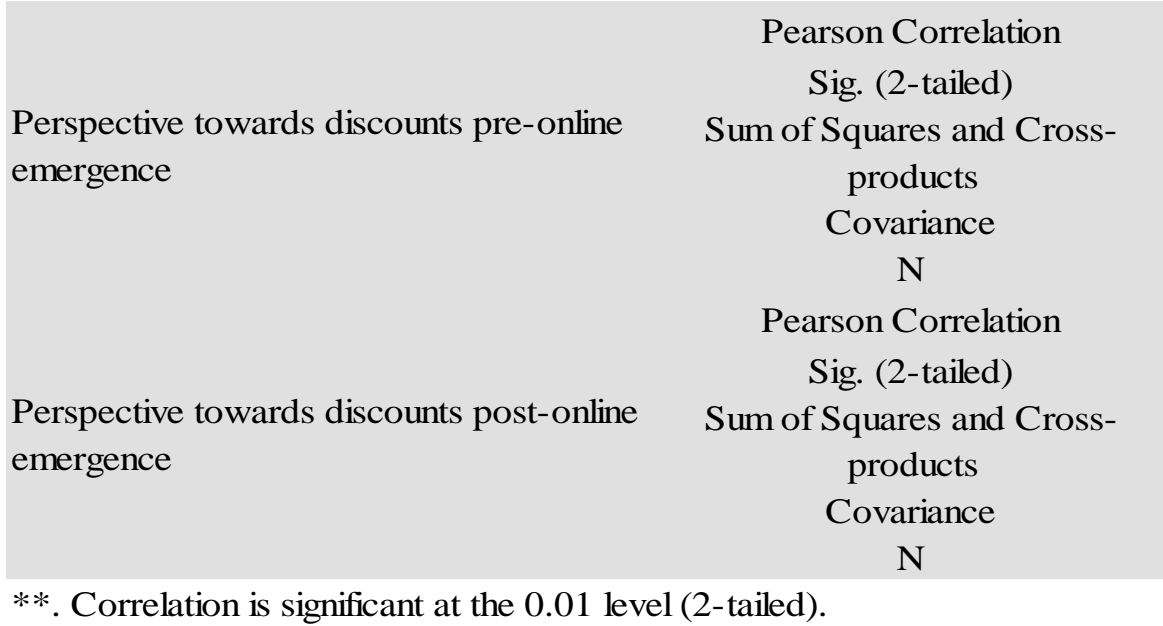

\section{Correlations}

$\begin{array}{cc}\begin{array}{c}\text { Perspective } \\ \text { towards } \\ \text { discounts pre- } \\ \text { online } \\ \text { emergence } \\ 1\end{array} & \begin{array}{c}\text { Perspective } \\ \text { towards } \\ \text { discounts post- } \\ \text { online } \\ \text { emergence } \\ \end{array} \\ \begin{array}{c}-.621^{* *} \\ 135.353\end{array} & 0 \\ 0.351 & -69.887 \\ 387 & 387 \\ -.621^{* *} & 1 \\ 0 & \\ -69.887 & 93.475 \\ -0.181 & 0.242 \\ 387 & 387\end{array}$
Perspective Perspective towards towards discounts pre- discounts postonline online

Correlation Coefficient Perspective towards discounts Sig. (2-tailed) $1-.463^{* *}$ pre-online emergence $\mathrm{N}$ Correlation Coefficient 387

Kendall's tau_b

Spearman's rho Perspective towards discounts
post-online emergence Sig. (2-tailed) $\mathrm{N}$ Correlation Coefficient $-.463^{* *}$ 387$$
0
$$
387 387 1 $-.589^{* *}$

Perspective towards discounts pre-online emergence

Sig. (2-tailed) $\mathrm{N}$ Correlation Coefficient 387 $-.589^{* *}$ 1

Perspective towards discounts post-online emergence
Sig. (2-tailed)

$\mathrm{N}$
0 387

**. Correlation is significant at the 0.01 level (2-tailed). 


\section{Correlations}

Kendall's tau_b

Spearman's rho

Perspective towards discounts pre-online emergence

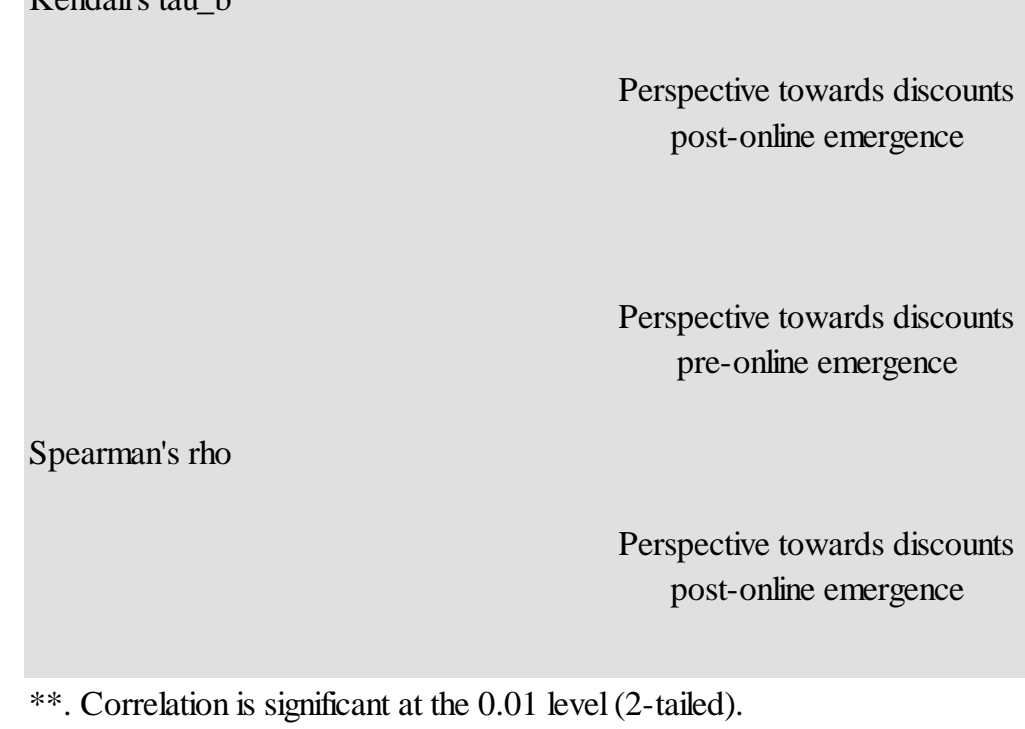

\section{Correlation}

Coefficient

Sig. (2-tailed)

$\mathrm{N}$

Correlation

Coefficient

Sig. (2-tailed)

$\mathrm{N}$

Correlation

Coefficient

Sig. (2-tailed)

$\mathrm{N}$

Correlation

Coefficient

Sig. (2-tailed)

N

\section{Perspective Perspective towards towards} discounts pre- discounts postonline online

$1-.463^{* *}$

. 0

$387 \quad 387$

$-.463^{* *}$

1

0

387

387

1

$-.589^{* *}$

0

$387 \quad 387$

$-.589^{* *}$

1

0

387

\begin{tabular}{|c|c|c|c|c|c|c|c|c|c|}
\hline \multicolumn{10}{|c|}{ Paired Samples Test } \\
\hline & & & & & & & $\mathrm{t}$ & df & $\begin{array}{l}\text { Sig. (2 } \\
\text { tailed) }\end{array}$ \\
\hline Pair 1 & $\begin{array}{l}\text { Perspective towards discounts pre-online } \\
\text { emergence - Perspective towards discounts } \\
\text { post-online emergence }\end{array}$ & 2.28174 & 1.25034 & 0.02401 & $\begin{array}{c}\text { Lower } \\
2.23466\end{array}$ & $\begin{array}{c}\text { Upper } \\
2.32882\end{array}$ & 95.035 & 2711 & 0.000 \\
\hline
\end{tabular}

\section{Findings - Consumer Perspective}

\section{Respondents Region}

Frequency Percent

North
East
West
South
Total

837
65
306
1504
2712

30.9

2.4

11.3

55.5

100 


\begin{tabular}{|c|c|c|c|c|c|}
\hline & & opping Prefe & nce & & \\
\hline & & Frequency & Percent & $\begin{array}{c}\text { Valid } \\
\text { Percent }\end{array}$ & $\begin{array}{c}\text { Cumulative } \\
\text { Percent }\end{array}$ \\
\hline & $\begin{array}{l}\text { Only Physical } \\
\text { Store }\end{array}$ & 4 & 0.1 & 0.1 & 0.1 \\
\hline Valid & $\begin{array}{l}\text { Both Physical } \\
\text { and Online } \\
\text { Store }\end{array}$ & 2004 & 73.9 & 73.9 & 74 \\
\hline & $\begin{array}{l}\text { Depends on } \\
\text { Product }\end{array}$ & 704 & 26 & 26 & 100 \\
\hline & Total & 2712 & 100 & 100 & \\
\hline
\end{tabular}

$\begin{array}{ll} & \\ & 20 \text { to } 25 \text { Years } \\ & 26 \text { to } 30 \text { Years } \\ & 31 \text { to } 35 \text { Years } \\ & 36 \text { to } 40 \text { Years } \\ \text { Valid } & \text { Above } 40 \\ & \text { Years } \\ & \text { Total }\end{array}$

\begin{tabular}{|c|c|c|c|}
\hline \multicolumn{2}{|l|}{ Age } & \multirow[b]{2}{*}{$\begin{array}{c}\text { Valid } \\
\text { Percent }\end{array}$} & \multirow[b]{2}{*}{$\begin{array}{c}\text { Cumulative } \\
\text { Percent }\end{array}$} \\
\hline Frequency & Percent & & \\
\hline 177 & 6.5 & 6.5 & 6.5 \\
\hline 721 & 26.6 & 26.6 & 33.1 \\
\hline 1506 & 55.5 & 55.5 & 88.6 \\
\hline 262 & 9.7 & 9.7 & 98.3 \\
\hline 46 & 1.7 & 1.7 & 100 \\
\hline 2712 & 100 & 100 & \\
\hline
\end{tabular}

\section{Gender}

$\begin{array}{ccc}\text { Frequency Percent } & \begin{array}{c}\text { Valid } \\ \text { Percent }\end{array} & \begin{array}{c}\text { Cumulative } \\ \text { Percent }\end{array}\end{array}$

$\begin{array}{llrrrr} & \text { Male } & 1308 & 48.2 & 48.2 & 48.2 \\ \text { Valid } & \text { Female } & 1404 & 51.8 & 51.8 & 100 \\ & \text { Total } & 2712 & 100 & 100 & \end{array}$

\section{Marital Status}

\begin{tabular}{|c|c|c|c|c|c|}
\hline & & Frequency & Percent & $\begin{array}{c}\text { Valid } \\
\text { Percent }\end{array}$ & $\begin{array}{c}\text { Cumulative } \\
\text { Percent }\end{array}$ \\
\hline \multirow{3}{*}{ Valid } & Married & 2503 & 92.3 & 92.3 & 92.3 \\
\hline & Unmarried & 209 & 7.7 & 7.7 & 100 \\
\hline & Total & 2712 & 100 & 100 & \\
\hline
\end{tabular}

\section{Education Level}

\begin{tabular}{|c|c|c|c|}
\hline Frequency & Percent & $\begin{array}{c}\text { Valid } \\
\text { Percent }\end{array}$ & $\begin{array}{c}\text { Cumulative } \\
\text { Percent }\end{array}$ \\
\hline 1740 & 64.2 & 64.2 & 64.2 \\
\hline 809 & 29.8 & 29.8 & 94 \\
\hline 163 & 6 & 6 & 100 \\
\hline 2712 & 100 & 100 & \\
\hline
\end{tabular}




\begin{tabular}{|c|c|c|c|c|c|}
\hline \multicolumn{6}{|c|}{ Shopping Experience } \\
\hline & & Frequency & Percent & $\begin{array}{c}\text { Valid } \\
\text { Percent }\end{array}$ & $\begin{array}{c}\text { Cumulative } \\
\text { Percent }\end{array}$ \\
\hline \multirow{6}{*}{ Valid } & 5 to 9 Years & 177 & 6.5 & 6.5 & 6.5 \\
\hline & 10 to 14 Years & 721 & 26.6 & 26.6 & 33.1 \\
\hline & 15 to 19 Years & 1506 & 55.5 & 55.5 & 88.6 \\
\hline & 20 to 24 Years & 262 & 9.7 & 9.7 & 98.3 \\
\hline & $\begin{array}{l}\text { Above } 25 \\
\text { Years }\end{array}$ & 46 & 1.7 & 1.7 & 100 \\
\hline & Total & 2712 & 100 & 100 & \\
\hline
\end{tabular}

Family Monthly Income

\begin{tabular}{|c|c|c|c|c|c|}
\hline & & Frequency & Percent & Percent & Percent \\
\hline \multirow{5}{*}{ Valid } & $\begin{array}{l}\text { Rs. } 26,000 \text { to } \\
\text { Rs. } 50,000\end{array}$ & 155 & 5.7 & 5.7 & 5.7 \\
\hline & $\begin{array}{l}\text { Rs. } 51,000 \text { to } \\
\text { Rs. } 75,000\end{array}$ & 994 & 36.7 & 36.7 & 42.4 \\
\hline & $\begin{array}{l}\text { Rs. } 76,000 \text { to } \\
\text { Rs. } 1,00,000\end{array}$ & 327 & 12.1 & 12.1 & 54.4 \\
\hline & $\begin{array}{l}\text { Above Rs. } \\
1,00,000\end{array}$ & 1236 & 45.6 & 45.6 & 100 \\
\hline & Total & 2712 & 100 & 100 & \\
\hline
\end{tabular}

Are you new to this store or is it your repeat visit?

\begin{tabular}{rrrr} 
Frequency & \multicolumn{1}{c}{ Percent } & \multicolumn{1}{c}{ Valid } & \multicolumn{2}{c}{$\begin{array}{c}\text { Cumulative } \\
\text { Percent }\end{array}$} & \multicolumn{1}{c}{ Percent } \\
1270 & 46.8 & 46.8 & 46.8 \\
1442 & 53.2 & 53.2 & 100 \\
2712 & 100 & 100 &
\end{tabular}

Q3. Prior to online stores boom, major discounts were given only during EOSS in physical stores.

\begin{tabular}{|c|c|c|c|c|c|}
\hline & & Frequency & Percent & Valid Percent & Cumulative Percent \\
\hline \multirow{5}{*}{ Valid } & Disagree & 84 & 3.1 & 3.1 & 3.1 \\
\hline & Neutral & 206 & 7.6 & 7.6 & 10.7 \\
\hline & Agree & 1348 & 49.7 & 49.7 & 60.4 \\
\hline & Strongly Agree & 1074 & 39.6 & 39.6 & 100 \\
\hline & Total & 2712 & 100 & 100 & \\
\hline
\end{tabular}

Q4. Prior to online stores boom, majority of time I was not expecting discounts during non EOSS periods.

\begin{tabular}{|c|c|c|c|c|c|}
\hline & & Frequency & Percent & Valid Percent & Cumulative Percent \\
\hline \multirow{5}{*}{ Valid } & Disagree & 77 & 2.8 & 2.8 & 2.8 \\
\hline & Neutral & 196 & 7.2 & 7.2 & 10.1 \\
\hline & Agree & 1366 & 50.4 & 50.4 & 60.4 \\
\hline & Strongly Agree & 1073 & 39.6 & 39.6 & 100 \\
\hline & Total & 2712 & 100 & 100 & \\
\hline
\end{tabular}

Q5. Prior to online stores boom, heavy discounts were offered only on old stocks during EOSS.

\begin{tabular}{|c|c|c|c|c|c|}
\hline & & Frequency & Percent & Valid Percent & Cumulative \\
\hline \multirow{6}{*}{ Valid } & $\begin{array}{l}\text { Strongly } \\
\text { Disagree }\end{array}$ & 3 & 0.1 & 0.1 & 0.1 \\
\hline & Disagree & 119 & 4.4 & 4.4 & 4.5 \\
\hline & Neutral & 157 & 5.8 & 5.8 & $10.3^{3}$ \\
\hline & Agree & 1358 & 50.1 & 50.1 & 60. \\
\hline & Strongly Agree & 1075 & 39.6 & 39.6 & 100 \\
\hline & Total & 2712 & 100 & 100 & \\
\hline
\end{tabular}

H. R. Ganesha, et al, (2020); www.srinivaspublication.com 
Q6. Prior to online stores boom, I used to buy more during EOSS than usual. Frequency Percent Valid Percent

$\begin{array}{ll} & \text { Strongly } \\ & \text { Disagree } \\ \text { Valid } & \text { Disagree } \\ & \text { Neutral } \\ & \text { Agree } \\ & \text { Strongly Agree } \\ & \text { Total }\end{array}$

$\begin{array}{cc}3 & 0.1 \\ 61 & 2.2 \\ 207 & 7.6 \\ 1370 & 50.5 \\ 1071 & 39.5 \\ 2712 & 100\end{array}$

0.1
2.2
7.6
50.5
39.5
100

Cumulative Percent
0.1
2.4
10
60.5
100

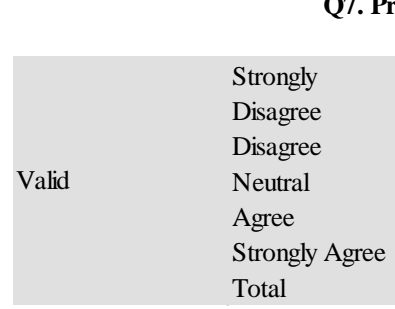

Q7. Prior to online stores boom, during EOSS it was highly encouraging to buy more than usual.

$\begin{array}{cccc}\text { Frequency } & \text { Percent } & \text { Valid Percent } & \text { Cumulative Percent } \\ 4 & 0.1 & 0.1 & 0.1 \\ 59 & 2.2 & 2.2 & 2.3 \\ 202 & 7.4 & 7.4 & 9.8 \\ 1372 & 50.6 & 50.6 & 60.4 \\ 1075 & 39.6 & 39.6 & 100 \\ 2712 & 100 & 100 & \end{array}$

Q8. Prior to online stores boom, during EOSS I could buy more for less.

Frequency Percent Valid Percent $\quad$ Cumulative Percent

$\begin{array}{ll} & \text { Strongly } \\ & \text { Disagree } \\ \text { Valid } & \text { Disagree } \\ & \text { Neutral } \\ & \text { Agree } \\ & \text { Strongly Agree } \\ & \text { Total }\end{array}$

$\begin{array}{cc}3 & 0.1 \\ 61 & 2.2 \\ 200 & 7.4 \\ 1374 & 50.7 \\ 1074 & 39.6 \\ 2712 & 100\end{array}$

0.1

0.1

2.4

9.7

60.4

100

Q9. Prior to online stores boom, I used to eagerly wait for July and January months as EOSS would start.

\begin{tabular}{clcccc} 
& & Frequency & Percent & Valid Percent & Cumulative Percent \\
& Disagree & 64 & 2.4 & 2.4 & 2.4 \\
\multirow{3}{*}{ Valid } & Neutral & 217 & 8 & 8 & 10.4 \\
& Agree & 1357 & 50 & 50 & 60.4 \\
& Strongly Agree & 1074 & 39.6 & 39.6 & 100 \\
& Total & 2712 & 100 & 100 &
\end{tabular}

Q10. Prior to online stores boom, EOSS event was a shopping festival.

$\begin{array}{clcccc} & & \text { Frequency } & \text { Percent } & \text { Valid Percent } & \text { Cumulative Percent } \\ & \text { Strongly Disagree } & 3 & 0.1 & 0.1 & 0.1 \\ \text { Valid } & \text { Disagree } & 81 & 3 & 3 & 3.1 \\ & \text { Neutral } & 186 & 6.9 & 6.9 & 10 \\ & \text { Agree } & 1370 & 50.5 & 50.5 & 60.5 \\ & \text { Strongly Agree } & 1072 & 39.5 & 39.5 & 100 \\ & \text { Total } & 2712 & 100 & 100 & \end{array}$

Q11. Prior to the online stores boom, it was not difficult to buy products at full price at any physical stores.

\begin{tabular}{|c|c|c|c|c|c|}
\hline & & Frequency & Percent & Valid Percent & Cumulative Percen \\
\hline \multirow{6}{*}{ Valid } & Strongly Disagree & 6 & 0.2 & 0.2 & 0.2 \\
\hline & Disagree & 70 & 2.6 & 2.6 & 2.8 \\
\hline & Neutral & 182 & 6.7 & 6.7 & 9.5 \\
\hline & Agree & 1371 & 50.6 & 50.6 & 60.1 \\
\hline & Strongly Agree & 1083 & 39.9 & 39.9 & 100 \\
\hline & Total & 2712 & 100 & 100 & \\
\hline
\end{tabular}


Q12. Post the online stores boom, I get discounts during non-EOSS periods also.

\begin{tabular}{|c|c|c|c|c|c|}
\hline \multirow{6}{*}{ Valid } & Strongly Agree & 1088 & 40.1 & 40.1 & 40.1 \\
\hline & Agree & 1325 & 48.9 & 48.9 & 89 \\
\hline & Neutral & 214 & 7.9 & 7.9 & 96.9 \\
\hline & Disagree & 84 & 3.1 & 3.1 & 100 \\
\hline & Strongly Disagree & 1 & 0 & 0 & 100 \\
\hline & Total & 2712 & 100 & 100 & \\
\hline
\end{tabular}

Q13. Post the online stores boom, I expect physical stores to match online discounts for the same product throughout the year.

\begin{tabular}{llcccc} 
& & Frequency & Percent & Valid Percent & Cumulative Percent \\
& Strongly Agree & 1075 & 39.6 & 39.6 & 39.6 \\
\multirow{4}{*}{ Valid } & 1368 & 50.4 & 50.4 & 90.1 \\
& Neutral & 188 & 6.9 & 6.9 & 97 \\
& Disagree & 76 & 2.8 & 2.8 & 99.8 \\
& Strongly Disagree & 5 & 0.2 & 0.2 & 100 \\
& Total & 2712 & 100 & 100 &
\end{tabular}

Q14. Post the online stores boom, discounts are also offered on new stocks in physical stores.

\begin{tabular}{clcccc} 
& & Frequency & Percent & Valid Percent & Cumulative Percent \\
\cline { 3 - 5 } Valid & Strongly Agree & 1079 & 39.8 & 39.8 & 39.8 \\
& Agree & 1367 & 50.4 & 50.4 & 90.2 \\
& Neutral & 185 & 6.8 & 6.8 & 97 \\
& Disagree & 79 & 2.9 & 2.9 & 99.9 \\
& Strongly Disagree & 2 & 0.1 & 0.1 & 100 \\
& Total & 2712 & 100 & 100 &
\end{tabular}

Q15. Post the online stores boom, I need not to wait for an EOSS event to buy more.

\begin{tabular}{|c|c|c|c|c|c|}
\hline & & Frequency & Percent & Valid Percent & Cumulative P \\
\hline \multirow{6}{*}{ Valid } & Strongly Agree & 1085 & 40 & 40 & 40 \\
\hline & Agree & 1361 & 50.2 & 50.2 & 90.2 \\
\hline & Neutral & 181 & 6.7 & 6.7 & 96.9 \\
\hline & Disagree & 80 & 2.9 & 3 & 99.9 \\
\hline & Strongly Disagree & 4 & 0.1 & 0.1 & 100 \\
\hline & Total & 2711 & 100 & 100 & \\
\hline Missing & System & 1 & 0 & & \\
\hline Total & & 2712 & 100 & & \\
\hline
\end{tabular}

Q16. Post the online stores boom, I usually threaten the physical store staff that I will buy from online store if they do not offer me better

\begin{tabular}{|c|c|c|c|c|c|}
\hline & & Frequency & Percent & Valid Percent & Cumulative Percer \\
\hline \multirow{6}{*}{ Valid } & Strongly Agree & 1075 & 39.6 & 39.7 & 39.7 \\
\hline & Agree & 1373 & 50.6 & 50.7 & 90.3 \\
\hline & Neutral & 180 & 6.6 & 6.6 & 97 \\
\hline & Disagree & 78 & 2.9 & 2.9 & 99.9 \\
\hline & Strongly Disagree & 4 & 0.1 & 0.1 & 100 \\
\hline & Total & 2710 & 99.9 & 100 & \\
\hline Missing & System & 2 & 0.1 & & \\
\hline Total & & 2712 & 100 & & \\
\hline
\end{tabular}

Q17. Post the online stores boom, during EOSS, I need not to buy more than usual as discounts are now available throughout the year online.

$\begin{array}{llcccr} & & \text { Frequency } & \text { Percent } & \text { Valid Percent } & \text { Cumulative Per } \\ & \text { Strongly Agree } & 1086 & 40 & 40.1 & 40.1 \\ & \text { Agree } & 1364 & 50.3 & 50.3 & 90.4 \\ \text { Valid } & \text { Neutral } & 176 & 6.5 & 6.5 & 96.9 \\ & \text { Disagree } & 83 & 3.1 & 3.1 & 100 \\ & \text { Strongly Disagree } & 1 & 0 & 0 & 100 \\ & \text { Total } & 2710 & 99.9 & 100 & \\ \text { Missing } & \text { System } & 2 & 0.1 & & \\ \text { Total } & & 2712 & 100 & \end{array}$


Q18. Post the online stores boom, EOSS event is conducted more times than earlier.

\begin{tabular}{|c|c|c|c|c|c|}
\hline & & Frequency & Percent & Valid Percent & Cumulative Percent \\
\hline \multirow{6}{*}{ Valid } & Strongly Agree & 1080 & 39.8 & 39.9 & 39.9 \\
\hline & Agree & 1376 & 50.7 & 50.8 & 90.6 \\
\hline & Neutral & 177 & 6.5 & 6.5 & 97.2 \\
\hline & Disagree & 76 & 2.8 & 2.8 & 100 \\
\hline & Strongly Disagree & 1 & 0 & 0 & 100 \\
\hline & Total & 2710 & 99.9 & 100 & \\
\hline Missing & System & 2 & 0.1 & & \\
\hline Total & & 2712 & 100 & & \\
\hline
\end{tabular}

Q19. Post the online stores boom, EOSS event is no more a most awaited shopping festival for me.

\begin{tabular}{clcccc} 
& & Frequency & Percent & Valid Percent & Cumulative Percent \\
& Strongly Agree & 1080 & 39.8 & 39.8 & 39.8 \\
\multirow{4}{*}{ Valid } & Agree & 1369 & 50.5 & 50.5 & 90.3 \\
& Neutral & 181 & 6.7 & 6.7 & 97 \\
& Disagree & 80 & 2.9 & 2.9 & 99.9 \\
& Strongly Disagree & 2 & 0.1 & 0.1 & 100 \\
& Total & 2712 & 100 & 100 &
\end{tabular}

Q20. Post the online stores boom, it is very difficult to buy products at full price at any physical stores.

\begin{tabular}{|c|c|c|c|c|c|}
\hline & & \multirow{2}{*}{$\begin{array}{c}\text { Frequency } \\
1083\end{array}$} & \multirow{2}{*}{$\begin{array}{c}\text { Percent } \\
39.9\end{array}$} & \multirow{2}{*}{$\begin{array}{c}\text { Valid Percent } \\
39.9\end{array}$} & \multirow{2}{*}{$\begin{array}{c}\text { Cumulative Percent } \\
39.9\end{array}$} \\
\hline & Strongly Agree & & & & \\
\hline \multirow{5}{*}{ Valid } & Agree & 1371 & 50.6 & 50.6 & 90.5 \\
\hline & Neutral & 182 & 6.7 & 6.7 & 97.2 \\
\hline & Disagree & 70 & 2.6 & 2.6 & 99.8 \\
\hline & Strongly Disagree & 6 & 0.2 & 0.2 & 100 \\
\hline & Total & 2712 & 100 & 100 & \\
\hline
\end{tabular}

Perspective towards discounts pre-online emergence

\begin{tabular}{|c|c|c|c|c|c|}
\hline & & Frequency & Percent & V alld Percent & Cumulative $\mathrm{F}$ \\
\hline & 1.78 & 6 & 0.2 & 0.2 & 0.2 \\
\hline & 1.89 & 8 & 0.3 & 0.3 & 0.5 \\
\hline & 2 & 49 & 1.8 & 1.8 & 2.3 \\
\hline & 3 & 156 & 5.8 & 5.8 & 8.1 \\
\hline & 3.33 & 4 & 0.1 & 0.1 & 8.2 \\
\hline & 3.44 & 2 & 0.1 & 0.1 & 8.3 \\
\hline & 3.56 & 20 & 0.7 & 0.7 & 9 \\
\hline & 3.67 & 40 & 1.5 & 1.5 & 10.5 \\
\hline Valid & 3.78 & 102 & 3.8 & 3.8 & 14.3 \\
\hline Valid & 3.89 & 159 & 5.9 & 5.9 & 20.1 \\
\hline & 4 & 1088 & 40.1 & 40.1 & 60.3 \\
\hline & 4.11 & 3 & 0.1 & 0.1 & 60.4 \\
\hline & 4.22 & 1 & 0 & 0 & 60.4 \\
\hline & 4.44 & 1 & 0 & 0 & 60.4 \\
\hline & 4.56 & 2 & 0.1 & 0.1 & 60.5 \\
\hline & 4.67 & 1 & 0 & 0 & 60.5 \\
\hline & 5 & 1070 & 39.5 & 39.5 & 100 \\
\hline & Total & 2712 & 100 & 100 & \\
\hline
\end{tabular}


Perspective towards discounts post-online emergence

$\begin{array}{cc} & 1.22 \\ 1.4 \\ 1.6 \\ 2.1 \\ 2.11 \\ 2.2 \\ 2.22 \\ 2.3 \\ \text { Valid } 2.33 \\ \\ \\ & 2.4 \\ & 2.5 \\ & 2.6 \\ & 2.7 \\ & 2.8 \\ & 3 \\ & 3.8 \\ & 3.9 \\ 4\end{array}$

Frequency

1

1072

2

31

1

1093

4

140

2

94

32

16

4

1

156

49

8

6

2712
Percent

0

39.5

0.1

1.1

0

40.3

0.1

5.2

0.1

3.5

1.2

0.6

0.1

0

5.8

1.8

0.3

0.2

100

\section{Correlations}

Perspective towards discounts pre-online emergence

Perspective towards discounts post-online emergence

**. Correlation is significant at the 0.01 level (2-tailed).

\section{Correlations}

Perspective towards discounts pre-online emergence

Kendall's tau_b

Perspective towards discounts
post-online emergence

Perspective towards discounts pre-online emergence

Spearman's rho

Perspective towards discounts post-online emergence
$\mathrm{N}$

Pearson Correlation

Sig. (2-tailed)

$\mathrm{N}$

\section{Pearson Correlation \\ Sig. (2-tailed)}

Valid Percent

0

39.5

0.1

1.1

0

40.3

0.1

5.2

0.1

3.5

1.2

0.6

0.1

0

5.8

1.8

0.3

0.2

100
Cumulative Percent

0

39.6

39.6

40.8

40.8

81.1

81.3

86.4

86.5

90

91.2

91.7

91.9

91.9

97.7

99.5

99.8

100
Perspective towards Perspective towards discounts pre-online discounts post-online emergence

$\begin{array}{cc}1 & -.990^{* *} \\ & 0 \\ 2712 & 2712 \\ -.990^{* *} & 1 \\ 0 & \\ 2712 & 2712\end{array}$

Perspective towards Perspective towards discounts pre-online discounts post-online emergence emergence
Correlation Coefficient Sig. (2-tailed) $\mathrm{N}$

Correlation Coefficient Sig. (2-tailed) $\mathrm{N}$

Correlation Coefficient Sig. (2-tailed)

$\mathrm{N}$

Correlation Coefficient Sig. (2-tailed) $\mathrm{N}$

$\begin{array}{cc}1 & -.880^{* *} \\ . & 0 \\ 2712 & 2712 \\ -.880^{* *} & 1 \\ 0 & . \\ 2712 & 2712 \\ 1 & -.935^{* *} \\ . & 0 \\ 2712 & 2712 \\ -.935^{* *} & 1 \\ 0 & . \\ 2712 & 2712\end{array}$

**. Correlation is significant at the 0.01 level (2-tailed). 


\section{T-TEST}

\section{Paired Samples Statistics}

Pair 1

Perspective towards discounts pre-online emergence

Perspective towards discounts post-online

emergence
Std. Std.

Mean N Deviati Error

on Mean

$\begin{array}{llll}4.267 & 2712 & 0.696 & 0.013\end{array}$

$\begin{array}{llll}1.985 & 2712 & 0.557 & 0.011\end{array}$

\section{Paired Samples Correlations}

$\begin{array}{lllll}\text { Perspective towards discounts pre-online } & & \\ \text { Pair } 1 & \text { emergence \& Perspective towards discounts post- } \\ \text { online emergence } & 2712 & -0.99 & 0\end{array}$

Paired Samples Test

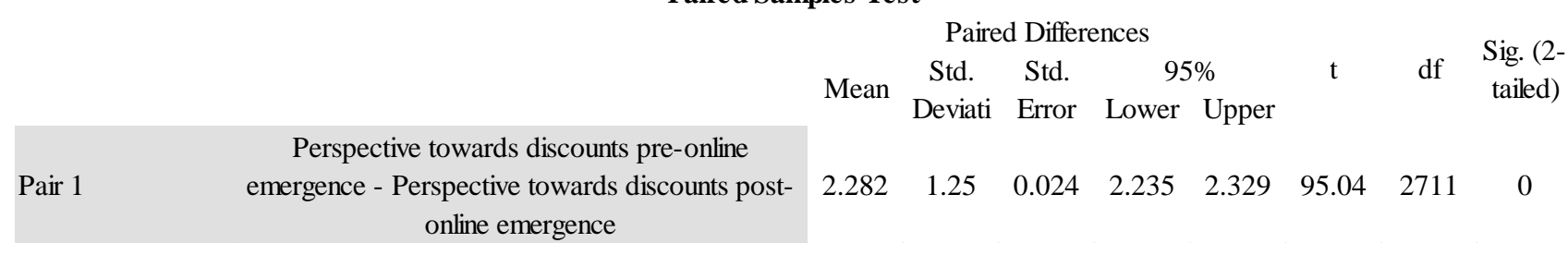

\section{Findings - Empirical data perspective}

\begin{tabular}{|c|c|c|c|c|c|c|c|c|c|c|}
\hline \multicolumn{2}{|c|}{ Descriptive Statistics } & \multirow{2}{*}{$\begin{array}{c}\text { N } \\
\text { Statistic }\end{array}$} & \multirow{2}{*}{$\begin{array}{l}\text { Minimum } \\
\text { Statistic }\end{array}$} & \multirow{2}{*}{$\begin{array}{l}\text { Maximum } \\
\text { Statistic }\end{array}$} & \multirow{2}{*}{$\begin{array}{c}\text { Mean } \\
\text { Statistic }\end{array}$} & \multirow{2}{*}{$\begin{array}{c}\text { Std. } \\
\text { Deviation } \\
\text { Statistic }\end{array}$} & \multirow{2}{*}{$\begin{array}{l}\text { Skewness } \\
\text { Statistic }\end{array}$} & \multirow[b]{2}{*}{ Std. Error } & \multirow{2}{*}{$\begin{array}{l}\text { Kurtosis } \\
\text { Statistic }\end{array}$} & \multirow[b]{2}{*}{ Std. Error } \\
\hline $\begin{array}{l}\text { Online store } \\
\text { emergence }\end{array}$ & Variables & & & & & & & & & \\
\hline \multirow{11}{*}{\begin{tabular}{|l|} 
Pre-Online \\
\\
\\
\end{tabular}} & Discount per cent & 60 & 0.01 & 0.28 & 0.0745 & 0.07063 & 0.998 & 0.309 & -0.022 & 0.608 \\
\hline & Bills per day per square foot & 60 & 0.01 & 0.01 & 0.0100 & 0.00180 & -0.072 & 0.309 & -0.565 & 0.608 \\
\hline & Average basket size & 60 & 2.23 & 3.08 & 2.6647 & 0.18237 & 0.186 & 0.309 & 0.226 & 0.608 \\
\hline & Average MRP (INR) & 60 & 538.42 & 723.68 & 611.2923 & 39.09133 & 0.723 & 0.309 & 0.263 & 0.608 \\
\hline & Average basket value (INR) & 60 & 1188.41 & 1530.99 & 1382.1168 & 7284902 & -0.198 & 0.309 & 0.713 & 0.608 \\
\hline & Volume per day per square foot (INR) & 60 & 0.02 & 0.04 & 0.0265 & 0.00495 & 0.334 & 0.309 & -0.461 & 0.608 \\
\hline & Average selling price (INR) & 60 & 407.88 & 611.42 & 520.4980 & 37.10459 & -0.452 & 0.309 & 0.754 & 0.608 \\
\hline & Revenue per day per square foot (INR) & 60 & 8.27 & 18.74 & 13.7322 & 2.28834 & -0.217 & 0.309 & -0.389 & 0.608 \\
\hline & Gross margin per day per square foot (INR) & 60 & 4.07 & 8.60 & 6.4014 & 0.98200 & -0.159 & 0.309 & -0.142 & 0.608 \\
\hline & Store profit per day per square foot (INR) & 60 & -1.40 & 2.10 & 0.5472 & 0.78227 & -0.242 & 0.309 & 0.131 & 0.608 \\
\hline & Valid N (listwise) & 60 & & & & & & & & \\
\hline \multirow[t]{11}{*}{ Post-Online } & Discount per cent & 60 & 0.07 & 0.41 & 0.1713 & 0.09313 & 1.131 & 0.309 & 0.253 & 0.608 \\
\hline & Bills per day per square foot & 60 & 0.01 & 0.02 & 0.0118 & 0.00297 & 0.349 & 0.309 & -0.616 & 0.608 \\
\hline & Average basket size & 60 & 2.51 & 3.88 & 3.0663 & 0.27195 & 0.327 & 0.309 & 0.908 & 0.608 \\
\hline & Average MRP (INR) & 60 & 654.18 & 854.11 & 727.0897 & 44.42958 & 0.676 & 0.309 & -0.110 & 0.608 \\
\hline & Average basket value (INR) & 60 & 1399.90 & 2064.48 & 1680.1193 & 125.95306 & 0.840 & 0.309 & 2.139 & 0.608 \\
\hline & Volume per day per square foot (INR) & 60 & 0.01 & 0.05 & 0.0360 & 0.00860 & -0.102 & 0.309 & -0.639 & 0.608 \\
\hline & Average selling price (INR) & 60 & 439.47 & 650.53 & 550.8090 & 49.38695 & -0.359 & 0.309 & -0.139 & 0.608 \\
\hline & Revenue per day per square foot (INR) & 60 & 8.72 & 29.15 & 19.6757 & 4.54101 & 0.118 & 0.309 & -0.636 & 0.608 \\
\hline & Gross margin per day per square foot (INR) & 60 & 2.91 & 12.95 & 7.9485 & 262788 & 0.037 & 0.309 & -0.927 & 0.608 \\
\hline & Store profit per day per square foot (INR) & 60 & -4.34 & 5.20 & 0.6985 & 2.39099 & -0.144 & 0.309 & -0.758 & 0.608 \\
\hline & Valid N (listwise) & 60 & & & & & & & & \\
\hline
\end{tabular}




\section{Descriptive Statistics}

\begin{tabular}{|c|c|c|c|}
\hline & Mean & $\begin{array}{c}\text { Std. } \\
\text { Deviation }\end{array}$ & $\begin{array}{c}\text { Analysis } \\
\mathrm{N}\end{array}$ \\
\hline Discount per cent & .1229 & .09559 & 120 \\
\hline $\begin{array}{l}\text { Bills per day per square } \\
\text { foot }\end{array}$ & .0109 & .00260 & 120 \\
\hline Average basket size & 2.8655 & .30627 & 120 \\
\hline Average MRP (INR) & 669.1910 & 71.53161 & 120 \\
\hline $\begin{array}{l}\text { Average basket value } \\
\text { (INR) }\end{array}$ & 1531.1181 & 181.34101 & 120 \\
\hline $\begin{array}{l}\text { Volume per day per } \\
\text { square foot (INR) }\end{array}$ & .0312 & .00849 & 120 \\
\hline $\begin{array}{l}\text { Average selling price } \\
\text { (INR) }\end{array}$ & 535.6535 & 46.08142 & 120 \\
\hline $\begin{array}{l}\text { Revenue per day per } \\
\text { square foot (INR) }\end{array}$ & 16.7039 & 4.66105 & 120 \\
\hline $\begin{array}{l}\text { Gross margin per day } \\
\text { per square foot (INR) }\end{array}$ & 7.1749 & 2.12259 & 120 \\
\hline $\begin{array}{l}\text { Store profit per day per } \\
\text { square foot (INR) }\end{array}$ & .6228 & 1.77301 & 120 \\
\hline
\end{tabular}

\section{Communalities}

\begin{tabular}{l|r|r} 
& Initial & \multicolumn{2}{|c}{\begin{tabular}{c} 
Extractio \\
\hline Discount per cent
\end{tabular}} & 1.000 & .953 \\
\hline $\begin{array}{l}\text { Bills per day per square } \\
\text { foot }\end{array}$ & 1.000 & .950 \\
\hline Average basket size & 1.000 & .797 \\
\hline Average MRP (INR) & 1.000 & .854 \\
\hline $\begin{array}{l}\text { Average basket value } \\
\text { (INR) }\end{array}$ & 1.000 & .923 \\
\hline $\begin{array}{l}\text { Volume per day per } \\
\text { square foot (INR) }\end{array}$ & 1.000 & .993 \\
\hline $\begin{array}{l}\text { Average selling price } \\
\text { (INR) }\end{array}$ & 1.000 & .954 \\
\hline $\begin{array}{l}\text { Revenue per day per } \\
\text { square foot (INR) }\end{array}$ & 1.000 & .995 \\
\hline $\begin{array}{l}\text { Gross margin per day } \\
\text { per square foot (INR) }\end{array}$ & 1.000 & .986 \\
\hline $\begin{array}{l}\text { Store profit per day per } \\
\text { square foot (INR) }\end{array}$ & 1.000 & .953 \\
\hline
\end{tabular}

Extraction Method: Principal Component

Analysis. 
International Journal of Management, Technology, and Social

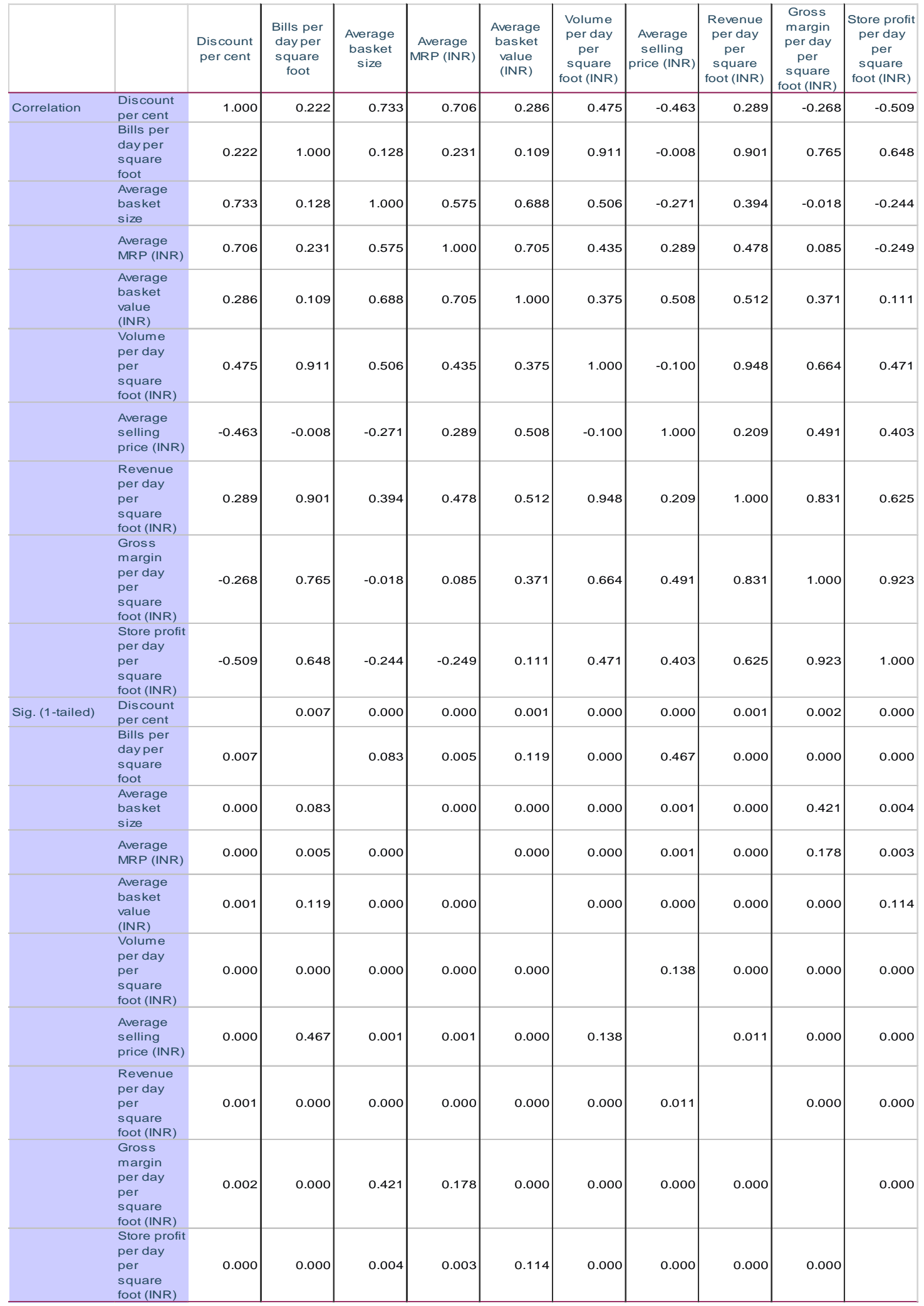


International Journal of Management, Technology, and Social

\begin{tabular}{|c|c|c|c|c|c|c|}
\hline \multirow[b]{3}{*}{ Component } & \multicolumn{5}{|c|}{ Total Variance Explained } & \\
\hline & & \multicolumn{2}{|c|}{ Initial Eigenvalues } & \multicolumn{2}{|c|}{ Extraction Sums of Squared Loadings } & \\
\hline & Total & $\begin{array}{c}\% \text { of } \\
\text { Variance }\end{array}$ & $\begin{array}{c}\text { Cumulative } \\
\%\end{array}$ & Total & $\begin{array}{c}\% \text { of } \\
\text { Variance }\end{array}$ & $\begin{array}{c}\text { Cumulative } \\
\%\end{array}$ \\
\hline $\begin{array}{l}\text { Discount } \\
\text { per cent }\end{array}$ & 4.627 & 46.266 & 46.266 & 4.627 & 46.266 & $46.26 t$ \\
\hline $\begin{array}{l}\text { Bills per } \\
\text { day per } \\
\text { square foot }\end{array}$ & 3.046 & 30.460 & 76.726 & 3.046 & 30.460 & 76.726 \\
\hline $\begin{array}{l}\text { Average } \\
\text { basket size }\end{array}$ & 1.684 & 16.844 & 93.570 & 1.684 & 16.844 & 93.57( \\
\hline $\begin{array}{l}\text { Average } \\
\text { MRP (INR) }\end{array}$ & .578 & 5.782 & 99.352 & & & \\
\hline $\begin{array}{l}\text { Average } \\
\text { basket } \\
\text { value (INR) }\end{array}$ & .034 & .343 & 99.695 & & & \\
\hline $\begin{array}{l}\text { Volume per } \\
\text { day per } \\
\text { square foot } \\
\text { (INR) }\end{array}$ & .015 & .147 & 99.842 & & & \\
\hline $\begin{array}{l}\text { Average } \\
\text { selling } \\
\text { price (INR) }\end{array}$ & .010 & .100 & 99.942 & & & \\
\hline $\begin{array}{l}\text { Revenue } \\
\text { per day per } \\
\text { square foot } \\
\text { (INR) }\end{array}$ & .004 & .037 & 99.978 & & & \\
\hline $\begin{array}{l}\text { Gross } \\
\text { margin per } \\
\text { day per } \\
\text { square foot } \\
\text { (INR) }\end{array}$ & .001 & .014 & 99.992 & & & \\
\hline $\begin{array}{l}\text { Store profit } \\
\text { per day per } \\
\text { square foot } \\
\text { (INR) }\end{array}$ & .001 & .008 & 100.000 & & & \\
\hline
\end{tabular}

Component Matrix ${ }^{a}$

\begin{tabular}{ll|r|r} 
& \multicolumn{3}{c}{ Component } \\
& 1 & 2 & \multicolumn{1}{c}{3} \\
\hline Discount per cent & .333 & .887 & -.236 \\
\hline $\begin{array}{l}\text { Bills per day per square } \\
\text { foot }\end{array}$ & .842 & -.221 & -.438 \\
\hline $\begin{array}{lll}\text { Average basket size } \\
\text { Average MRP (INR) }\end{array}$ & .478 & .753 & .038 \\
\hline $\begin{array}{l}\text { Average basket value } \\
\text { (INR) }\end{array}$ & .622 & .321 & .658 \\
\hline $\begin{array}{l}\text { Volume per day per } \\
\text { square foot (INR) }\end{array}$ & .926 & .102 & -.353 \\
\hline $\begin{array}{l}\text { Average selling price } \\
\text { (INR) }\end{array}$ & .256 & -.439 & .834 \\
\hline $\begin{array}{l}\text { Revenue per day per } \\
\text { square foot (INR) }\end{array}$ & .989 & -.075 & -.102 \\
\hline $\begin{array}{l}\text { Gross margin per day } \\
\text { per square foot (INR) }\end{array}$ & .805 & -.579 & .056 \\
\hline $\begin{array}{l}\text { Store profit per day per } \\
\text { square foot (INR) }\end{array}$ & .576 & -.785 & -.063 \\
\hline Extraction Method: Principal Component Analysis.
\end{tabular}

a. 3 components extracted. 


\section{Component Score Coefficient Matrix}

\begin{tabular}{|c|c|c|c|}
\hline & \multicolumn{3}{|c|}{ Component } \\
\hline & 1 & 2 & 3 \\
\hline Discount per cent & .072 & .291 & -.140 \\
\hline $\begin{array}{l}\text { Bills per day per square } \\
\text { foot }\end{array}$ & .182 & -.073 & -.260 \\
\hline Average basket size & .103 & .247 & .023 \\
\hline Average MRP (INR) & .120 & .202 & .241 \\
\hline $\begin{array}{l}\text { Average basket value } \\
\text { (INR) }\end{array}$ & .134 & .105 & .391 \\
\hline $\begin{array}{l}\text { Volume per day per } \\
\text { square foot (INR) }\end{array}$ & .200 & .033 & -.210 \\
\hline $\begin{array}{l}\text { Average selling price } \\
\text { (INR) }\end{array}$ & .055 & -.144 & .495 \\
\hline $\begin{array}{l}\text { Revenue per day per } \\
\text { square foot (INR) }\end{array}$ & .214 & -.025 & -.061 \\
\hline $\begin{array}{l}\text { Gross margin per day } \\
\text { per square foot (INR) }\end{array}$ & .174 & -.190 & .033 \\
\hline $\begin{array}{l}\text { Store profit per day per } \\
\text { square foot (INR) }\end{array}$ & .125 & -.258 & -.037 \\
\hline
\end{tabular}

Extraction Method: Principal Component Analysis.

\section{Component Score Covariance Matrix}

\begin{tabular}{lr|r|r} 
Component & \multicolumn{1}{l|}{1} & \multicolumn{1}{c|}{2} & \multicolumn{1}{c}{3} \\
\hline 1 & 1.000 & .000 & .000 \\
\hline 2 & .000 & 1.000 & .000 \\
\hline 3 & .000 & .000 & 1.000 \\
\hline
\end{tabular}

Extraction Method: Principal Component Analysis. 
International Journal of Management, Technology, and Social

SRINIVAS

Sciences (IJMTS), ISSN: 2581-6012, Vol. 5, No. 1, April 2020.

PUBLICATION

\section{T-Test}

Paired Samples Statistics

\begin{tabular}{|c|c|c|c|c|c|c|}
\hline \multicolumn{3}{|c|}{ Online store emergence } & \multirow{2}{*}{$\begin{array}{l}\text { Mean } \\
.0745\end{array}$} & \multirow{2}{*}{$\frac{N}{60}$} & \multirow{2}{*}{$\begin{array}{r}\text { Std. Deviation } \\
.07063\end{array}$} & \multirow{2}{*}{$\begin{array}{l}\begin{array}{l}\text { Std. Error } \\
\text { Mean }\end{array} \\
.00912\end{array}$} \\
\hline Pre-Onli & Pair 1 & Discount per cent & & & & \\
\hline & & $\begin{array}{l}\text { Bills per day per square } \\
\text { foot }\end{array}$ & .0100 & 60 & .00180 & .00023 \\
\hline & \multirow[t]{2}{*}{ Pair 2} & Discount per cent & .0745 & 60 & .07063 & .00912 \\
\hline & & Average basket size & 2.6647 & 60 & .18237 & .02354 \\
\hline & \multirow[t]{2}{*}{ Pair 3} & Discount per cent & .0745 & 60 & .07063 & .00912 \\
\hline & & Average MRP (INR) & 611.2923 & 60 & 39.09133 & 5.04667 \\
\hline & \multirow[t]{2}{*}{ Pair 4} & Discount per cent & .0745 & 60 & .07063 & .00912 \\
\hline & & $\begin{array}{l}\text { Volume per day per } \\
\text { square foot (INR) }\end{array}$ & .0265 & 60 & .00495 & .00064 \\
\hline & \multirow[t]{2}{*}{ Pair 5} & Discount per cent & .0745 & 60 & .07063 & .00912 \\
\hline & & $\begin{array}{l}\text { Average selling price } \\
\text { (INR) }\end{array}$ & 520.4980 & 60 & 37.10459 & 4.79018 \\
\hline & \multirow[t]{2}{*}{ Pair 6} & Discount per cent & .0745 & 60 & .07063 & .00912 \\
\hline & & $\begin{array}{l}\text { Revenue per day per } \\
\text { square foot (INR) }\end{array}$ & 13.7322 & 60 & 2.28834 & .29542 \\
\hline & \multirow[t]{2}{*}{ Pair 7} & Discount per cent & .0745 & 60 & .07063 & .00912 \\
\hline & & $\begin{array}{l}\text { Gross margin per day per } \\
\text { square foot (INR) }\end{array}$ & 6.4014 & 60 & .98200 & .12678 \\
\hline & \multirow[t]{2}{*}{ Pair 8} & Discount per cent & .0745 & 60 & .07063 & .00912 \\
\hline & & $\begin{array}{l}\text { Store profit per day per } \\
\text { square foot (INR) }\end{array}$ & .5472 & 60 & .78227 & .10099 \\
\hline \multirow[t]{16}{*}{ Post-Onl } & \multirow[t]{2}{*}{ Pair 1} & Discount per cent & .1713 & 60 & .09313 & .01202 \\
\hline & & $\begin{array}{l}\text { Bills per day per square } \\
\text { foot }\end{array}$ & .0118 & 60 & .00297 & .00038 \\
\hline & \multirow[t]{2}{*}{ Pair 2} & Discount per cent & .1713 & 60 & .09313 & .01202 \\
\hline & & Average basket size & 3.0663 & 60 & .27195 & .03511 \\
\hline & \multirow[t]{2}{*}{ Pair 3} & Discount per cent & .1713 & 60 & .09313 & .01202 \\
\hline & & Average MRP (INR) & 727.0897 & 60 & 44.42958 & 5.73583 \\
\hline & \multirow[t]{2}{*}{ Pair 4} & Discount per cent & .1713 & 60 & .09313 & .01202 \\
\hline & & $\begin{array}{l}\text { Volume per day per } \\
\text { square foot (INR) }\end{array}$ & .0360 & 60 & .00860 & .00111 \\
\hline & \multirow[t]{2}{*}{ Pair 5} & Discount per cent & .1713 & 60 & .09313 & .01202 \\
\hline & & $\begin{array}{l}\text { Average selling price } \\
\text { (INR) }\end{array}$ & 550.8090 & 60 & 49.38695 & 6.37583 \\
\hline & \multirow[t]{2}{*}{ Pair 6} & Discount per cent & .1713 & 60 & .09313 & .01202 \\
\hline & & $\begin{array}{l}\text { Revenue per day per } \\
\text { square foot (INR) }\end{array}$ & 19.6757 & 60 & 4.54101 & .58624 \\
\hline & \multirow[t]{2}{*}{ Pair 7} & Discount per cent & .1713 & 60 & .09313 & .01202 \\
\hline & & $\begin{array}{l}\text { Gross margin per day per } \\
\text { square foot (INR) }\end{array}$ & 7.9485 & 60 & 2.62788 & .33926 \\
\hline & \multirow[t]{2}{*}{ Pair 8} & Discount per cent & .1713 & 60 & .09313 & .01202 \\
\hline & & $\begin{array}{l}\text { Store profit per day per } \\
\text { square foot (INR) }\end{array}$ & .6985 & 60 & 2.39099 & .30868 \\
\hline
\end{tabular}

H. R. Ganesha, et al, (2020); www.srinivaspublication.com

PAGE 79 


\section{Paired Samples Correlations}

\begin{tabular}{|c|c|c|c|c|c|}
\hline \multicolumn{3}{|c|}{ Online store emergence } & \multirow{2}{*}{$\frac{N}{60}$} & \multirow{2}{*}{$\begin{array}{r}\text { Correlation } \\
.489\end{array}$} & \multirow{2}{*}{$\frac{\text { Sig. }}{.000}$} \\
\hline Pre-Onli & Pair 1 & $\begin{array}{l}\text { Discount per cent \& Bills } \\
\text { per day per square foot }\end{array}$ & & & \\
\hline & Pair 2 & $\begin{array}{l}\text { Discount per cent \& } \\
\text { Average basket size }\end{array}$ & 60 & .627 & .000 \\
\hline & Pair 3 & $\begin{array}{l}\text { Discount per cent \& } \\
\text { Average MRP (INR) }\end{array}$ & 60 & .468 & .000 \\
\hline & Pair 4 & $\begin{array}{l}\text { Discount per cent \& } \\
\text { Volume per day per } \\
\text { square foot (INR) }\end{array}$ & 60 & .707 & .000 \\
\hline & Pair 5 & $\begin{array}{l}\text { Discount per cent } \& \\
\text { Average selling price } \\
\text { (INR) }\end{array}$ & 60 & -.682 & .000 \\
\hline & Pair 6 & $\begin{array}{l}\text { Discount per cent \& } \\
\text { Revenue per day per } \\
\text { square foot (INR) }\end{array}$ & 60 & .450 & .000 \\
\hline & Pair 7 & $\begin{array}{l}\text { Discount per cent } \& \\
\text { Gross margin per day per } \\
\text { square foot (INR) }\end{array}$ & 60 & -.159 & .225 \\
\hline & Pair 8 & $\begin{array}{l}\text { Discount per cent \& Store } \\
\text { profit per day per square } \\
\text { foot (INR) }\end{array}$ & 60 & -.326 & .011 \\
\hline \multirow[t]{8}{*}{ Post-Onl } & Pair 1 & $\begin{array}{l}\text { Discount per cent \& Bills } \\
\text { per day per square foot }\end{array}$ & 60 & -.135 & .305 \\
\hline & Pair 2 & $\begin{array}{l}\text { Discount per cent \& } \\
\text { Average basket size }\end{array}$ & 60 & .610 & .000 \\
\hline & Pair 3 & $\begin{array}{l}\text { Discount per cent \& } \\
\text { Average MRP (INR) }\end{array}$ & 60 & .662 & .000 \\
\hline & Pair 4 & $\begin{array}{l}\text { Discount per cent \& } \\
\text { Volume per day per } \\
\text { square foot (INR) }\end{array}$ & 60 & .073 & .579 \\
\hline & Pair 5 & $\begin{array}{l}\text { Discount per cent } \& \\
\text { Average selling price } \\
\text { (INR) }\end{array}$ & 60 & -.831 & .000 \\
\hline & Pair 6 & $\begin{array}{l}\text { Discount per cent \& } \\
\text { Revenue per day per } \\
\text { square foot (INR) }\end{array}$ & 60 & -.250 & .054 \\
\hline & Pair 7 & $\begin{array}{l}\text { Discount per cent } \& \\
\text { Gross margin per day per } \\
\text { square foot (INR) }\end{array}$ & 60 & -.715 & .000 \\
\hline & Pair 8 & $\begin{array}{l}\text { Discount per cent \& Store } \\
\text { profit per day per square } \\
\text { foot (INR) }\end{array}$ & 60 & -.733 & .000 \\
\hline
\end{tabular}




\begin{tabular}{|c|c|c|c|c|c|c|c|c|c|c|}
\hline \multicolumn{11}{|c|}{ Paired Samples Test } \\
\hline \multirow{3}{*}{\multicolumn{3}{|c|}{ Online store emergence }} & \multirow[b]{3}{*}{ Mean } & \multirow[b]{3}{*}{ Std. Deviation } & \multicolumn{3}{|c|}{ Paired Differences } & \multirow[b]{3}{*}{$t$} & \multirow[b]{3}{*}{ df } & \multirow[b]{3}{*}{ Sig. (2-tailed) } \\
\hline & & & & & \multirow{2}{*}{$\begin{array}{l}\text { Std. Error } \\
\text { Mean }\end{array}$} & \multicolumn{2}{|c|}{$\begin{array}{l}95 \% \text { Confidence Interval of the } \\
\text { Difference }\end{array}$} & & & \\
\hline & & & & & & Lower & Upper & & & \\
\hline \multirow[t]{8}{*}{ Pre-Onli } & Pair 1 & $\begin{array}{l}\text { Discount per cent - Bills } \\
\text { per day per square foot }\end{array}$ & .06452 & .06977 & .00901 & .04649 & .08254 & 7.163 & 59 & .000 \\
\hline & Pair 2 & $\begin{array}{l}\text { Discount per cent- } \\
\text { Average basket size }\end{array}$ & -2.59022 & .14868 & .01919 & -2.62862 & -2.55181 & -134.946 & 59 & .000 \\
\hline & Pair 3 & $\begin{array}{l}\text { Discount per cent - } \\
\text { Average MRP (INR) }\end{array}$ & -611.21782 & 39.05835 & 5.04241 & -621.30766 & -601.12798 & -121.215 & 59 & .000 \\
\hline & Pair 4 & $\begin{array}{l}\text { Discount per cent- } \\
\text { Volume per day per } \\
\text { square foot (INR) }\end{array}$ & .04807 & .06722 & .00868 & .03070 & .06543 & 5.539 & 59 & .000 \\
\hline & Pair 5 & $\begin{array}{l}\text { Discount per cent- } \\
\text { Average selling price } \\
\text { (INR) }\end{array}$ & -520.42348 & 37.15279 & 4.79640 & -530.02107 & -510.82590 & -108.503 & 59 & .000 \\
\hline & Pair 6 & $\begin{array}{l}\text { Discount per cent - } \\
\text { Revenue per day per } \\
\text { square foot (INR) }\end{array}$ & -13.65768 & 2.25745 & .29144 & -14.24084 & -13.07452 & -46.863 & 59 & .000 \\
\hline & Pair 7 & $\begin{array}{l}\text { Discount per cent - Gross } \\
\text { margin per day per } \\
\text { square foot (INR) }\end{array}$ & -6.32685 & .99568 & .12854 & -6.58406 & -6.06964 & -49.220 & 59 & .000 \\
\hline & Pair 8 & $\begin{array}{l}\text { Discount per cent - Store } \\
\text { profit per day per square } \\
\text { foot (INR) }\end{array}$ & -.47268 & .80805 & .10432 & -.68142 & -.26394 & -4.531 & 59 & .000 \\
\hline \multirow[t]{8}{*}{ Post-Onl } & Pair 1 & $\begin{array}{l}\text { Discount per cent-Bills } \\
\text { per day per square foot }\end{array}$ & .15958 & .09358 & .01208 & .13541 & .18376 & 13.210 & 59 & .000 \\
\hline & Pair 2 & $\begin{array}{l}\text { Discount per cent- } \\
\text { Average basket size }\end{array}$ & -2.89492 & .22745 & .02936 & -2.95367 & -2.83616 & -98.589 & 59 & .000 \\
\hline & Pair 3 & $\begin{array}{l}\text { Discount per cent- } \\
\text { Average MRP (INR) }\end{array}$ & -726.91833 & 44.36797 & 5.72788 & -738.37979 & -715.45687 & -126.909 & 59 & .000 \\
\hline & Pair 4 & $\begin{array}{l}\text { Discount per cent- } \\
\text { Volume per day per } \\
\text { square foot (INR) }\end{array}$ & .13530 & .09290 & .01199 & .11130 & .15930 & 11.281 & 59 & .000 \\
\hline & Pair 5 & $\begin{array}{l}\text { Discount per cent - } \\
\text { Average selling price } \\
\text { (INR) }\end{array}$ & -550.63767 & 49.46436 & 6.38582 & -563.41566 & -537.85967 & -86.228 & 59 & .000 \\
\hline & Pair 6 & $\begin{array}{l}\text { Discount per cent- } \\
\text { Revenue per day per } \\
\text { square foot (INR) }\end{array}$ & -19.50433 & 4.56520 & .58936 & -20.68365 & -18.32502 & -33.094 & 59 & .000 \\
\hline & Pair 7 & $\begin{array}{l}\text { Discount per cent - Gross } \\
\text { margin per day per } \\
\text { square foot (INR) }\end{array}$ & -7.77717 & 2.69525 & .34795 & -8.47342 & -7.08091 & -22.351 & 59 & .000 \\
\hline & Pair 8 & $\begin{array}{l}\text { Discount per cent - Store } \\
\text { profit per day per square } \\
\text { foot (INR) }\end{array}$ & -.52717 & 2.46011 & .31760 & -1.16268 & .10835 & -1.660 & 59 & .102 \\
\hline
\end{tabular}

\section{Analysis Framework (R1 Vs. R2 Vs. R3)}

\section{Variables}

Discount per cent and Bills per day per square foot

Discount per cent and Average basket size

Discount per cent and Average MRP

Discount per cent and Volume per day per square foot

Discount per cent and Average selling price

Discount per cent and Revenue per day per square foot

Discount per cent and Gross margin per day per square foot

Discount per cent and Store profit per day per square foot

Online emergence type and Store profit per day per square foot

\section{Correlation Coefficient}

Retailer Consumer Empirical Retailer Consumer Empiric Suvey

$-0.62$

Survey

Data

$-0.270$

$-0.621$

$-0.135$

$-0.940$

0.610

$-0.270$

$-0.940$

0.662

$-0.389$

$-0.935$

0.073

$-0.389$

$-0.935$

$-0.389$

$-0.935$

$-0.286$

$-1.000$

$-0.831$

$-0.250$

$-0.715$

$-0.286$

$-1.000$

$-0.733$

$-0.990$
T Test Sig. (2-tailed) Survey Survey Data

\begin{tabular}{l|l|l}
\hline 0.000 & 0.000 & 0.000
\end{tabular}

\begin{tabular}{l|l|l}
\hline 0.000 & 0.000 & 0.000
\end{tabular}

\begin{tabular}{l|l|l}
\hline 0.000 & 0.000 & 0.000
\end{tabular}

\begin{tabular}{l|l|l}
\hline 0.000 & 0.000 & 0.000
\end{tabular}

\begin{tabular}{l|l|l|l}
\hline 0.000 & 0.000 & 0.000
\end{tabular}

\begin{tabular}{l|l|l}
0.000 & 0.000 & 0.000
\end{tabular}

\begin{tabular}{l|l|l}
0.000 & 0.000 & 0.000
\end{tabular}

\begin{tabular}{l|l|l}
0.000 & 0.000 & 0.000
\end{tabular}

\begin{tabular}{l|l|l}
\hline 0.000 & 0.000 & 0.102
\end{tabular} 


\section{Analysis Framework (Pre-Online Vs. Post-Online)}

\begin{tabular}{|l|c|c|c|c|}
\hline & \multicolumn{2}{|c|}{ Corre lation } & \multicolumn{2}{c|}{ Sig. (2-tailed) } \\
\hline Variables under empirical data analysis & Pre-Online & Post-Online & Pre-Online & Post-Online \\
\hline Discount per cent and Bills per day per square foot & 0.489 & -0.135 & 0.000 & 0.000 \\
Discount per cent and Average basket size & 0.627 & 0.610 & 0.000 & 0.000 \\
Discount per cent and Average MRP & 0.468 & 0.662 & 0.000 & 0.000 \\
Discount per cent and Volume per day per square foot & 0.707 & 0.073 & 0.000 & 0.000 \\
Discount per cent and Average selling price & -0.682 & -0.831 & 0.000 & 0.000 \\
Discount per cent and Revenue per day per square foot & 0.450 & -0.250 & 0.000 & 0.000 \\
Discount per cent and Gross margin per day per square foot & -0.159 & -0.715 & 0.000 & 0.000 \\
Discount per cent and Store profit per day per square foot & -0.326 & -0.733 & 0.000 & 0.000 \\
Online emergence type and Store profit per day per square foot & -0.326 & -0.733 & 0.000 & 0.102 \\
\hline
\end{tabular}

\section{Pre-Online Vs. Post-Online)}

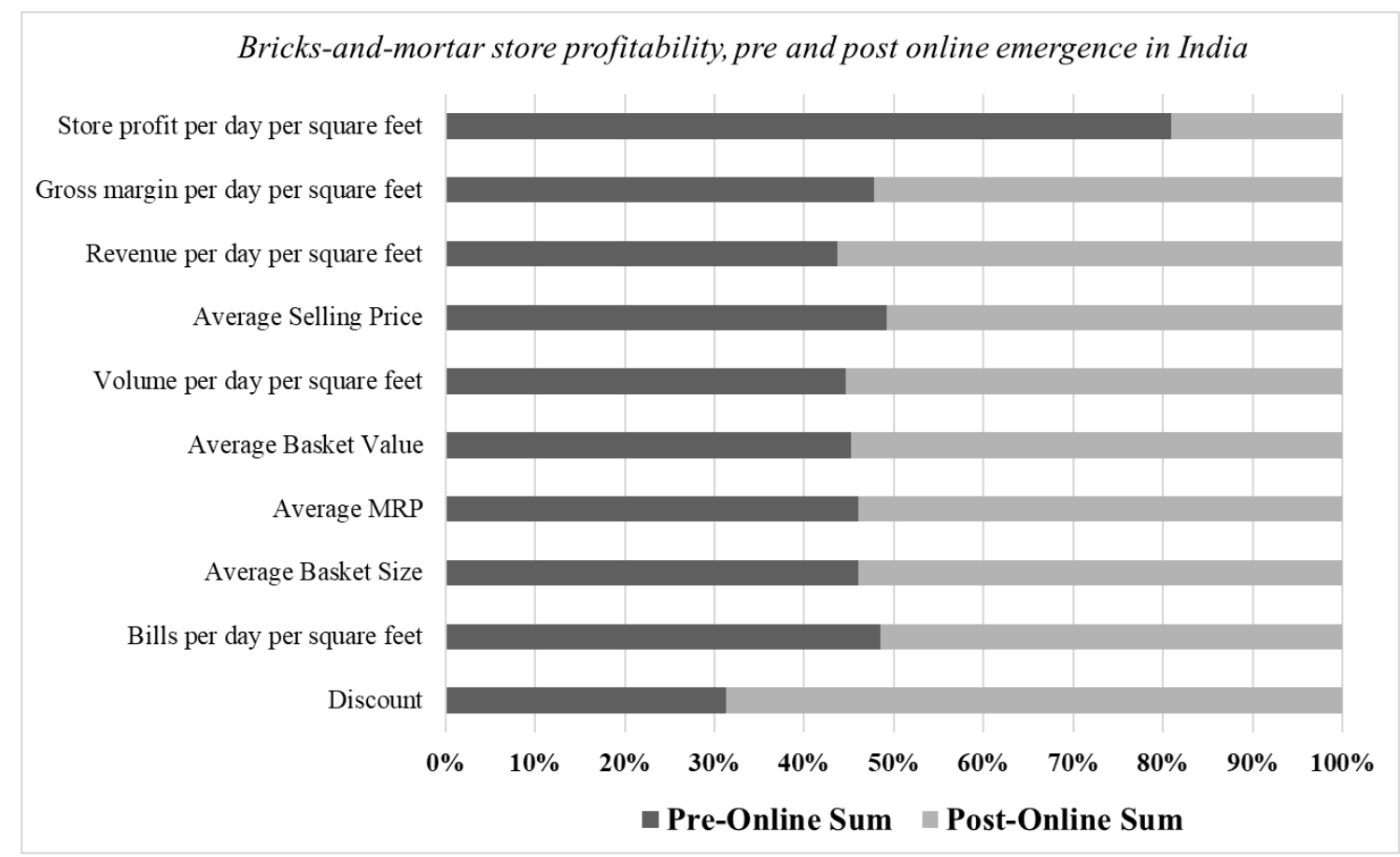




\section{Correlation coefficients}

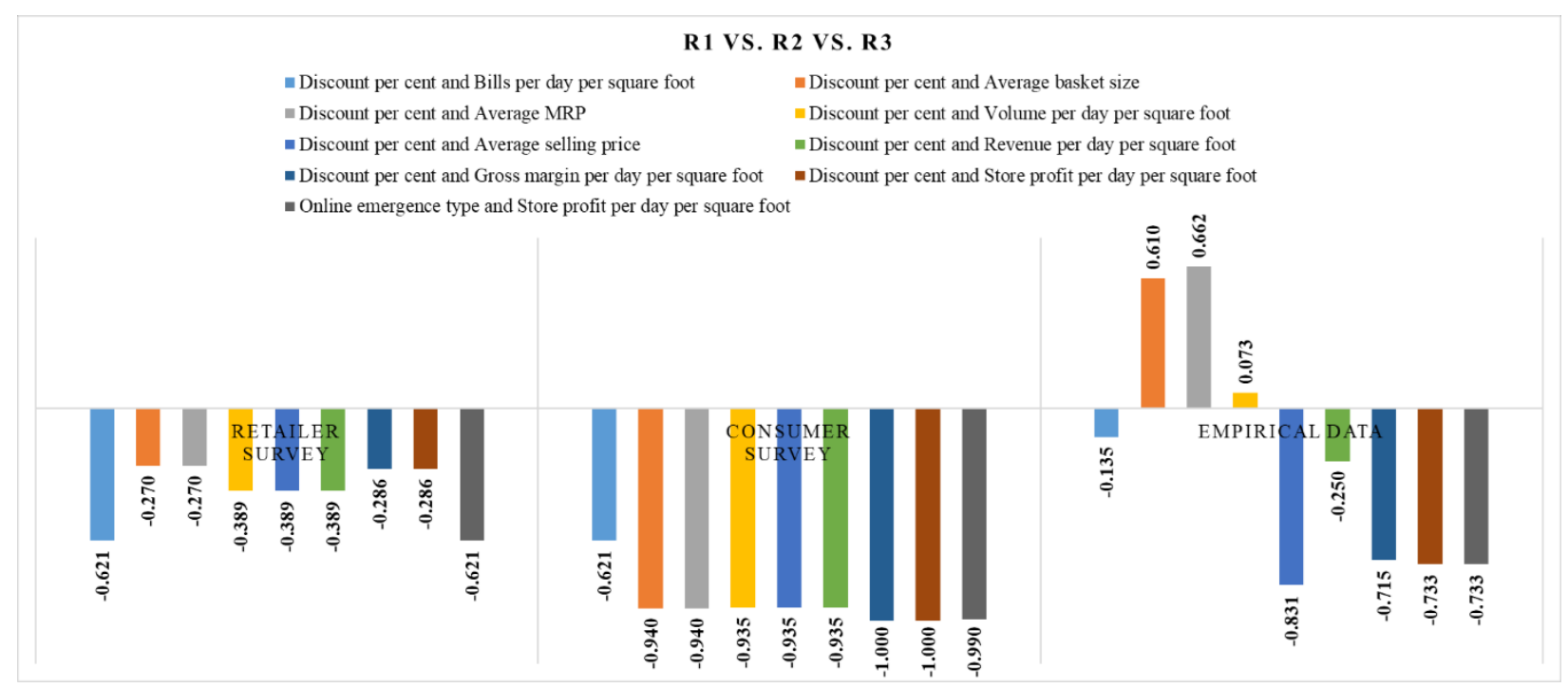

